\title{
Notes on some British Nudibranchs.
}

\author{
By \\ C. Eliot, \\ Vice-Chancellor of the University of Sheffield. \\ With Plates XI and XII.
}

THE following notes are the result partly of an examination of various living specimens at Plymouth in the spring of 1905 , and partly of the study of preserved material most kindly placed at my disposal by Mr. E. J. Allen and Mr. W. I. Beaumont, of the Laboratory, Plymouth, Mr. W. E. Hoyle, of the Manchester University Museum, and the Council of the Hancock Museum at Newcastle. I must also express my thanks and obligations to Mr. T. J. Evans, lecturer in Biology at the University of Sheffield, who has prepared for me sections of the smaller specimens and embodied the results in drawings which will add very materially to any value which this paper may have.

The following are the species noticed:-

1. Tritonia alba, A. \& H.

2. Staurodoris verrucosa (Cuvier).

3. Archidoris testudinaria (A. \& H.).

4. Geitodoris planata (A. \& H.).

5. Lamellidoris bilamellata (L.).

6. L. oblonga (A. \& H.).

7. L. depressa (A. \& H.).

8. L. pusilla (A. \& H.).

9. Pleurophyllidia loveni, Bergh.

10. Lomanotus genei, Vérany.

11. L. marmoratus, A. \& H.

12. L. flavidus, A. \& H.

13. Hancockia dactylota, Gosse.

14. Doto pinnatifida, A. \& H., var. papillifera.

15. Berghia corulescens (Laurillard).

16. Coryphella rufibranchialis (Johnst.).

17. C. gracilis (A. \& H.).

18. C. landsburghii (A. \& H.).

19. C. beaumonti, spec. nov.

20. Eolis angulata, A. \& H.

21. Amphorina aurantiaca (A. \& H), ( = Cuthona aurantiaca.) 
22. Amphorina olivacea (A. \& H.). (=Cratena olivacea.)

23. Cratena amona (A. \& H.).

24. Calma glaucoides (A. \& H.).

25. Antiopella cristata (Delle Chiaje).

26. Janolus hyalinus (A. \& H.).

27. Janolus flagellatus, sp. nov.

28. Alderia modesta, Lovén.

29. Stiliger bellulus (d'Orbigny).

Of the above, Coryphella beaumonti and Janolus flagellatus are new species. The first may be regarded as certain, though it offers so many peculiarities that its place in the genus Coryphella is open to question. Janolus flagellatus differs from other described species in its genitalia, but cannot be regarded as certain until better preserved specimens are examined. Berghia ccerulescens must be removed from the list of the British fauna, for the only recorded specimen is a Facelina coronata; but Staurodoris verrucosa may be added, for it seems to be certainly, though sporadically, recorded from Devonshire, the Clyde, and West Ireland.

An examination of the type specimen of Tritonia alba, A. \& H., has enabled me to show that this species, which has been called in question, is valid and well characterized. The valuable material with which I have been supplied has, I hope, enabled me to amplify our knowledge of Lomanotus, Hancockia, Alderia, and Calma. The systematic position of the last genus appears to me to have been misunderstood; Calma glaucoides belongs to the same genus as the later Forestia mirabilis of Trinchese, but Calma cavolini must be removed from this group, as it does not possess the characteristic radula.

I have also attempted to elucidate the synonymy and affinities of Alder and Hancock's Doris testudinaria, which appears to be a fairly common form, though often confounded with Archidoris tuberculata, and have also examined the classification of the Cratenidæ. I think that the genus Amphorina must be referred to this group, and that the animals described as Cratena olivacea and Cuthona aurantiaca are really referable to Amphorina. Eolis angulata is probably a young Eolidiella glauca.

\section{TRITONIA.}

A species of this genus which has been called in doubt is now shown to be valid by an examination of the type specimen, and the following additions may be recorded to Tritonia and Candiella, of which Bergh recognized sixteen species in the System der Nudibranchiaten Gasteropoden, 1892. I do not think that the distinction between Tritonia and 
Candiella can be maintained (vide Eliot, "On the Nudibranchiata of the Scottish National Antarctic Expedition," Trans. Roy. Soc. Edinb., vol. xli. part iii. p. 523, 1905).

17. T. alba, A. \& H.

18. T. exsulans, B.

19. T. incerta, B.

20. T. gigantea, B.

21. T. (Candiella) australis, B.

22. T. (Cand.) ingolfiana, B.

23. T. (Cand.) villafranca, Vayssière.

24. T. appendiculata, Eliot.

$(?=T$. challengeriana, var.)

25. T. olivacea, B.

26. T. irrorata, B.

TRITONIA ALBA, A. \& H.

(Monogr. of the British Nudib. Mollusca, part vii. p. 48, and

Appendix, p. vi.)

Specimens of this form were found by Alder and Hancock at Cullercoats, near Newcastle, and described by them as having considerable external resemblance to young individuals of $T$. hombergii, but as differing in dentition from all known Tritonias, inasmuch as the lateral teeth were denticulate or branched. Bergh (Mal. Unt. in Semper's Reisen, Heft xv. pp. 734 and 736) rejects the species as doubtful, and thinks that the denticles were merely an illusion of the microscope. An examination of the original specimens preserved in the Hancock Museum at Newcastle-on-Tyne has shown me, however, that this is not the case, and that the teeth are really denticulate.

The two specimens are respectively 7 and $6 \mathrm{~mm}$. long, and 2.8 and $2.2 \mathrm{~mm}$. broad. One is dark brown, the other yellowish. The hard buccal parts are fortunately well preserved, otherwise few characters either external or internal can be established, which is hardly surprising, as the specimen must be at least fifty years old. There is no reason, however, to doubt the accuracy of Alder and Hancock's descriptions. The dorsal margin is large, and seems to have borne in the one specimen six, in the other eight branchiæ of various sizes. No trace of stomach plates was found.

The jaws are yellow, rather long and narrow, and bear near the edge about four rows of small prominences resembling a mosaic. The radula is very transparent, and consists of twenty-five rows, which appear to contain thirty-six teeth on each side of the rhachis when complete. The rhachidian tooth (Pl. XI., Fig. 1. a.) is tricuspid, and hollowed out 
below. The first lateral (Pl. XI., Fig. 1. b.) is of the usual clumsy shape, but is rather variable in outline. The second lateral (Pl. XI., Fig. 1. c.) is smooth, moderately stout, and simply hamate. The succeeding teeth become longer and slenderer towards the outside. The third lateral bears a prominence or rudimentary denticle, and the remaining laterals in the middle of the half-row (Pl. XI., Fig. 1. d. e. f.), bear from one to three long branch-like denticles, and sometimes one or two accessory shorter ones. Towards the end of the row the denticles are found only at the tip of the teeth, and the outermost (Pl. XI., Fig. 1. g.) are elongate and bifid. This peculiarity is not marked in Alder and Hancock's plate, which otherwise gives a very accurate representation of the radula.

STAURODORIS, BERGH.

It is worthy of consideration if this genus should not bear the Linnæan name of Doris. Bergh (Mal. Unt. in Semper's Reisen, xiv. p. 616) decided to discontinue the use of this name (" besser wäre es, wie hier geschieht, den Namen Doris als generische Bezeichnung ganz zu streichen "). But there seem at least two objections to this course. Firstly, if an old genus is divided into sub-genera, one of these new sub-genera should, according to the rule generally recognized, bear the name of the old genus. Secondly, it would appear that in Staurodoris verrucosa, Bergh, the use of the specific name really admits that the animal is the Linnæan Doris. The type of Doris is Doris verrucosa of the tenth edition of the Systema Naturce. It is true that the animal cannot be recognized from Linnæus's description, but Cuvier identified it rightly or wrongly with a Mediterranean form, and Cuvier's animal has been renamed Staurodoris verrucosa by Bergh. But this form can bear the specific name verrucosa only on the supposition that it is the Doris verrucosa of Linnæus. Therefore either it is Doris verrucosa, or else Staurodoris with a new specific name; but it cannot logically be Staurodoris verrucosa.

Further, it seems a pity to abolish a well-known name used by so many eminent naturalists, and in my opinion the use of Doris is not only correct, but convenient. I cannot help thinking that the distinctions between Bergh's genera of the Archidorididæ are somewhat minute, and that a juster classification would be secured by the use of the genus Doris (type Doris verrucosa), to include as sub-genera at least Staurodoris, Archidoris, Anisodoris, and possibly others.

Staurodoris, Bergh, cannot in my opinion be satisfactorily separated from Archidoris, Bergh, as the two genera are connected by their less typical members. The typical Staurodoris has simply pinnate branchiæ and the back studded with clavate tubercles, which form valves round the rhinophores and branchiæ. But in the less typical form the 
branchiæ become bi- or tripinnate and the valvular tubercles less distinct.* The following forms would perhaps be referable to the subgenus Staurodoris :-

1. St. verrucosa (Cuvier).

St. pseudovervucosa, Jher.

St. januarii, Bergh.

2. St. bertheloti (d'Orbigny).

3. St. d'orbignyi (Gray).

4. St. pustulata (Abraham).

[See Hedley and Basedow, Trans. Roy. Soc.

S. Australia, vol. xxix., 1905, p. 150, pl. ix.]

5. St. maculata (Garstang).

6. St. depressa, Eliot.

7. St. calva, Eliot.

8. St. bicolor, Bergh.

9. St. rusticata (A. \& H.).

10. ? St. pecten, Eliot.

11. ? St. flabellifera (Cheeseman).

The last two species have a peculiar configuration of the branchiæ, which renders their inclusion in this genus doubtful. St. bertheloti and St. d'orbignyi are only known from very imperfect descriptions.

\section{STAURODORIS VERRUCOSA (CUV.).}

Two specimens from the Museum of the Manchester University, labelled as coming from the Firth of Clyde. The larger is $35 \mathrm{~mm}$. long and 21 broad; the other slightly smaller. The details given below refer to the larger specimen, unless otherwise stated.

Both specimens are depressed, rather stiff and hard, uniform whitish yellow in colour. The back is studded with large and small tubercles. There are fifteen of the former, about $3 \mathrm{~mm}$. high and $2 \mathrm{~mm}$. broad. Smaller ones are scattered among them, and the tubercles decrease in size towards the edge of the mantle, which is fairly wide. The foot is broad; no groove or notch is visible on the anterior margin. The tentacles are ridge-like.

The rhinophore pockets are protected by four tubercles (two large and two small) in the smaller specimen and by three in the other, one of the smaller tubercles not being developed. The branchiæ are simply pinnate, eighteen in the larger specimen, fourteen in the smaller. The pocket has a thin slightly raised lip, bearing eight tall, slender tubercles about $3.5 \mathrm{~mm}$. high, alternating fairly regularly with quite small ones.

The intestines are yellowish, except the stomach, which is black from

* Vayssière's figure of the Mediterranean Archidoris tuberculata (Opisth, de Marseille, iii. pl. 1, fig. 1) seems to me to have the external characters of Staurodoris. 
the colour of its contents. The spermatotheca is very large. The formula of the yellowish radula is $55 \times$ about 60.0 .60 . The teeth are simply hamate, and rather crowded. The outermost are degraded, but not denticulate. In the anterior, but not in the posterior rows, the innermost teeth project somewhat into the rhachis, which bears longitudinal folds.

St. verrucosa has already been recorded from the British marine area by Mr. G. P. Farran, who found one specimen at Fahy Bar, Ballynakill, West Ireland (Ann. Rep. Fish. Ireland, 1902-3, part. ii. app. vii. [1905] pp. 207-8). Bergh in his systematic arrangement of the Nudibranchiata unites with it St. januarii, St. ocelligera, and St. pseudoverrucosa, and including these varieties the species is now recorded from the Mediterranean and Adriatic; the coast of Brazil, the Atlantic coast of Europe, and South Carolina.

\section{STAURODORIS VERRUCOSA (CUV.), VAR. MOLLIS.}

One specimen, labelled Salcombe, R. A. Todd, 3. VIII. 1900. The measurements are: length, $21 \mathrm{~mm}$; breadth, 12 ; height, 7 . The colour is white, with a faint yellowish tinge; the texture soft. The foot is $17 \mathrm{~mm}$. long and 6 broad, with a longish free tail; it has slight traces of a groove in front, but no notch. The mantle edge is ample, and measures about $4 \mathrm{~mm}$. The tentacles consist of a ridge-like prominence on either side of the mouth; they are attached for the greater part of their length, and show slight traces of a fold. The back is somewhat sparsely tuberculate. Down the centre run six fairly regular longitudinal lines of large tubercles, about $1.5 \mathrm{~mm}$. wide and $1 \mathrm{~mm}$. high. Between them and on the mantle edge are smaller tubercles. A few tubercles near the branchiæ are taller and almost clavate. There is no trace of ridges connecting the various tubercles. The rhinophores are deeply perfoliate, and emerge between two tubercles. The rim of the branchial pocket is slightly raised, and bears ten tubercles of various sizes, but all quite distinct. The largest are $1 \mathrm{~mm}$. high. The branchiæ are simply pinnate, the pinnæ being alternately long and short. They project about $4.5 \mathrm{~mm}$. from the pocket, and lie flat on the back like a star. Seen thus they appear to be thirteen, but on opening the pocket it is seen that nine are long and separate, and four small, springing from the sides of the longer ones. All the plumes are united at the base in a common circular band, which bears papillæ outside. The anal papilla is central.

The intestines are white. In the central nervous system the cerebropleural ganglia are above the pedal, which as preserved lie below them at the side. The eyes are black and distinct. 
The buccal mass is elongate. In one part of the labial cuticle is a mass of variously shaped spicules, which are apparently the remains of a fragment of food embedded in the skin, and do not represent an armature of the lips. The radula is colourless, with a maximum formula of $40 \times 45.0 .45$. The teeth are rather straight and only slightly hamate. Towards the end of the rows the spike becomes reduced and the base increases, with the result that the tooth resembles a broad, clumsy hook. The two innermost teeth project into the rhachis, and are lower than the rest, but not denticulate.

The œsophagus is thin, and the salivary glands band-like. The stomach lies in an upper anterior cleft of the liver, but is separate from it. Its walls are thickish, with a strong irregular lamination. The genitalia seem to be as in the typical form. The light-grey hermaphrodite gland is spread over the greenish liver. The spermatotheca is large and spherical; the spermatocyst much smaller and elliptical. No armature was found.

I have compared this animal with specimens of St. verrucosa from the Mediterranean. It is lighter in colour, very much softer in consistency, and the tubercles are lower and, as a rule, not clavate. But these are all matters of degree, and I do not think a new species can be created on the evidence of a single specimen.

The present specimen is superficially quite unlike St. maculata (Garstang), which is very convex, hard, and bears a pattern of knobs connected by ridges.

\section{ARCHIDORIS TESTUDINARIA (A. \& H.).}

[Doris testudinaria, Alder and Hancock, Ann. and Mag. H. N., 1862, vol. x., 3rd series, p. 261.

? Doris testudinaria, Risso. Hist. Nat. de l'Eur. Mer., iv., 1826, p. 33. Archidoris stellifera, H. von Jhering. See VAyssik̀re, Journal de Conchyl., vol. lii. No. 2, 1904, p. 123. Id. Opist. de Marseille Supp., p. $82,1903$.

Doris testudinaria. Jeffrey's British Conchology, vol. v. p. 85 (written by Alder, as stated on p. 27).]

Both the nomenclature and the specific limits of this form present many difficulties, and it is with great diffidence that I submit it should be called Archidoris testudinaria, that it is identical with the Archidoris stellifera of Vayssière and von Jhering, and that it is probably distinct from the Doris planata of Alder and Hancock. Two points, however, seem certain: first, that the specimens from Plymouth here described are the Doris testudinaria of Alder and Hancock; second, that they are distinct from Archidoris tuberculata, with which they are often confounded in practice. 
In 1862 Alder and Hancock described (l.c.) a new British Dorid, which they identified with the D. testudinaria of Risso. From some unpublished notes preserved in the Hancock Museum at Newcastle-onTyne, it is probable that they based this identification, not on Risso's description, but on specimens sent from the Mediterranean and labelled D. testudinaria, which they considered identical with their specimen from Herm Island.* Risso's description is vague, inadequate, and, as pointed out first by Philippi (Enum. Moll. Sicil., vol. ii. p. 78), probably inaccurate. Bergh and others have thought that it refers to Platydoris argo. But since Alder and Hancock have given the name to a fully described animal, which is possibly identical with Risso's animal, it would seem that their interpretation of the name must be regarded as authoritative. After Alder and Hancock had assigned the name $D$. testudinaria to an identifiable form, von Jhering gave the name Archidoris stellifera to Mediterranean specimens, which seem to me to belong to the same species. His description appears to have been only in MS., and publication dates from the memoires of Vayssière, who uses the same name. As will be seen from the notes here given, stellate forms are found on the British coast, and appear to be specifically the same as the less ornate variety described by Alder and Hancock. It is remarkable, however, that Vayssière states that the mouth of his specimens is armed with a chitinous ring. I could not discover this structure in the specimen which he kindly sent to me.

Alder and Hancock, in the Ann. and Mag. of Nat. Hist., l.c., expressed the opinion that $D$. testudinaria and $D$. planata are distinct though similar species. Subsequently Alder in Jeffrey's Conchology (1.c.) came round to the opposite view, and stated that an examination of further specimens of different sizes from the Clyde proved that $D$. planata is the young of $D$. testudinaria. It is extremely difficult to form any decided opinion on this question. The external characters are likely to vary considerably at different periods of the animal's growth, and it would appear that in $D$. testudinaria (stellifera) a labial armature may or may not be developed. Vayssière reports its presence, and Alder and Hancock (Ann. and Mag. N. H., l.c.) say of D. testudinaria and D. planata, "the character of the tongue is similar in each." On the other hand, in a number of specimens from Plymouth which I have examined, I have found a decided labial armature in the small flat individuals and none at all in the large plump ones. It is present in the specimen of $D$. planata from Alder and Hancock's collection at Newcastle. On the whole I am inclined to think that there are two separate forms which are very much alike in their younger stages.

- It is even possible that A. \& H. may have obtained the specimens from Risso, or from some one who knew the animal which he called $D$. testudinaria. They were writing about Nudibranchs in 1841 , but probably began collecting earlier. 
(1) D. planata. This is a remarkably flat form, which appears not to exceed an inch in length in British waters. The dorsal surface is finely granulated, there is a distinct labial armature, and the radula is decidedly of the type of Geitodoris, Bergh, that is to say, there are two kinds of teeth, the inner teeth being of the ordinary hamate shape, and the outer very thin and crowded together in sheaves. It is possible that some specimens (about $50 \mathrm{~mm}$. long) which $\mathrm{I}$ have received from the Cape Verde Islands may be adults of this species. They resemble the Plymouth specimens, except that they are much larger and were red in life. The richer colour may perhaps be due to the climate.

(2) D. testudinaria. This is a plump form of considerable size $(60 \mathrm{~mm}$.). The back is covered with flat tubercles, which are sometimes arranged in a stellate pattern. In the specimens from Plymouth, which I have myself examined, there is no labial armature, but Vayssière states that it is present in the Mediterranean form, which is otherwise undistinguishable. The radula is not unlike that of the last species, but the differentiation of the teeth is less marked. The outer are thinner than the inner ones, but the change is less abrupt, and the thinner teeth are not gathered together in such distinct sheaves or packets.

The names Platydoris testudinaria and Platydoris planata would seem to be in any case incorrect, for none of the animals have the characters of Platydoris (which include a peculiar hard consistency and an armature of hooked scales on the reproductive organs). It is possible, but not demonstrable, that the Doris testudinaria of Risso was a Platydoris; but, if so, it is neither the $D$. testudinaria nor the $D$. planata of Alder and Hancock.

Alder and Hancock's type specimen labelled "Doris testudinaria, Herm," has been kindly lent me by the Council of the Hancock Museum, Newcastle.

It is $30 \mathrm{~mm}$. long, 23 broad, and 15 high. The mantle margin is broken in many places, but it apparently covered the sides and the foot entirely in its original condition. The general colour of the animal is greyish yellow. Some of the dorsal tubercles are lighter than the surrounding surface. There are some reddish spots on the under side of the mantle.

The texture is soft, and the specimen is a little decayed. The back is covered with low flat warts of various sizes. No stellate arrangement is visible. The branchial and rhinophorial pockets are surrounded by tubercles which do not amount to valves. The branchiæ are retracted within the pocket, and their number could not be ascertained. The anterior part of the animal is much retracted, but the long linear tentacles are clearly visible. 
The buccal parts have been extracted.

No further examination was made in order not to injure the unique specimen.

I have also examined five specimens seen alive at Plymouth in April, 1905. They vary somewhat in external appearance, and may be described separately.

A. One specimen, rather variable in shape, but flattish. When fully stretched out and moving its length is $60 \mathrm{~mm}$. and its breadth 32 . It is active in its motions. The main colour of the back is mottled purplish brown of various shades, the deepest of which is almost black. The general colour is lighter towards the margin, though here the darker shades are more conspicuous by contrast. There are a few irregular sandy-grey markings here and there, especially in front of the rhinophores, and twelve sandy-yellow star-like figures arranged symmetrically in four lines between the rhinophores and the branchial pocket. The back is covered with flat tubercles, very slightly prominent, and more or less of the same size (not more than $1 \mathrm{~mm}$. in breadth), except those forming the centre of the stars, which are about twice as large as the others. The tubercles forming the stars appear to be set in a stellate figure, but the pattern is due to pigment rather than to the arrangement of the tubercles. The edge of the rhinophore pockets is set with small tubercles. The rhinophores are elongate, with about fifteen perfoliations. They are olive coloured, and the stalk is long compared with the laminated part. The branchial pocket is slightly raised and tuberculate. The branchiæ are six, tripinnate, sandy yellow, with purplish flecks. The anal papilla is purplish, but the edge is crenulate and distinctly margined with sandy yellow. The foot is grooved in front and the upper lamina notched. The tentacles are cylindrical and elongate, which makes the whole head look unlike that of $A$. tuberculata. The under side is white, but in this and in all the specimens there are a few purplish spots on the under side of the mantle, which is rather ample and overhangs the foot all round.

B. In a second specimen of about the same size the characters are exactly the same, but there are only four stellate figures on each side, and they are less regular both in their formation and their arrangement. The pockets of the rhinophores and the branchiæ are very distinctly crenulate and tuberculate.

C. Three similar but rather smaller specimens are paler in colour, and the stellate figures are only imperfectly developed. The branchiæ are as many as seven or eight.

The internal characters of all the specimens are much the same. The blood gland is large, double, purple or greyish. The central nervous system is not quite as in $A$. tuberculata. Seen from the upper 
side, the ganglia appear united in a horseshoe-shaped mass in which no divisions are clearly distinguished. Seen from below, the division between the cerebro-pleural and pedal ganglia is plain, but the cerebropleural ganglia are not distinctly divided into two portions. The common commissure is thick and very short.

The integuments, especially the tuberculate dorsal surface, are very spiculous, and contain a dense mass of colourless rods, often slightly bent, but not swollen in the middle, jointed, or branched.

No labial armature could be found, but on the labial cuticle in some specimens were granular markings resembling grey dust, but not forming rods or compact plates. The radula consists of about thirty rows, and the number of teeth on each side of the rhachis does not appear to much exceed forty as a maximum; but the whole radula is fragile and difficult to extend. The teeth are transparent and colourless, longer and thinner than in $A$. tuberculata, and with narrower bases. Near the rhachis (Fig. 2. a. b.) the teeth are low and with comparatively broad bases; but they increase in length and slenderness towards the outside until the last two or three, which are shorter, but often somewhat deformed (Fig. 2. f.). Teeth with abnormal lumps and projections occur in all parts of the radula (Fig. 2. d.).

The œsophagus is narrow at first, but widens and enters the liver. The stomach lies within the liver. The gall bladder is small and pearshaped. The intestine issues from the liver about the middle of its dorsal surface, runs forward and then turns backward. The liver is of a dull orange colour; the hermaphrodite gland, spread over it, is of a dull opaque white.

The spermatotheca is large, greenish or bluish grey, and spherical. The spermatocyst is small, white or orange-white, less distinctly spherical, and sometimes pear-shaped. There is no prostate. The vas deferens is very slender, long, and convoluted. The penis small, conical, and unarmed. The duct seems to issue at the side of the tip.

Though this species is commonly confused with $A$. tuberculata, it seems to differ in the following points :-

(1) The typical coloration is different, though it is very often imperfectly developed. But there are nearly always purple spots on the lower side of the mantle, which seem not to occur in A. tuberculata.

(2) The general form is flatter.

(3) The shape of the tentacles and anterior part of the foot is markedly different.

(4) The tubercles are less prominent and of more equal size.

(5) The branchiæ are stouter and less voluminous.

(6) The shape of the teeth is different.

(7) The stomach is enclosed within the liver. 
For purposes of comparison I have examined a specimen of A. stellifera, most kindly sent me from Marseilles by Professor Vayssière. It is $31 \mathrm{~mm}$. long, 16 broad, and $10 \mathrm{high}$, flattish and rather smooth, with low even tubercles. The colour of the dorsal surface is dark olivebrown of various shades; the larger tubercles are yellowish, but the stellate appearance is hardly visible. The under side is pinkish, with reddish brown dots on the lower surface of the mantle. The oral tentacles are longish, conical, and somewhat flattened. The anterior margin of the foot is grooved and perhaps notched, but this is difficult to decide. The edge of the rhinophore pockets is set with small inconspicuous tubercles. The branchiæ are eight; the edge of the pocket is tuberculate, much like the rest of the back, but has no special tubercles of its own. The formula of the radula is about $18 \times 30.0 .30$ and the shape of the teeth as described above for the Plymouth specimens.

Neither in this specimen, nor in those from Plymouth, could I find any trace of the armature described by Professor Vayssière (l.c.) as "anneau chitineux mandibulaire, complet, assez large, offrant dans la partie interne de petits et très courts bâtonnets prismatiques." Nothing was visible but a thick unarmed cuticle.

Vayssière refers this form to Archidoris, and I follow him; but if the external teeth are longer and thinner than the internal ones, and if, as Vayssière has found, a labial armature is sometimes present, it is clear that the division between Archidoris and Geitodoris is not so sharp as might be supposed. It would be interesting to have statistics as to the uniform presence or absence of the labial armature in various species. There certainly seems to be ground for suspecting that in some species of Archidoris and Staurodoris it is generally absent, but occasionally present, though not much developed. With reference to this and many other organs, we have little information as to the effect of age and growth on the external and internal characters of Nudibranchs.

\section{GEITODORIS PLANATA (A. \& H.).}

(Alder and Hancock, Monograph, Plate VIII., and Part VII. p. 42. Eliot, Proc. Mal. Society of London, Sept., 1904, vol. vi. No. 3, pp. 180-1.)

In the paper cited above I have described specimens caught at Plymouth, and considered in the Laboratory to be $D$. planata, A. \& H., and have also given my reasons for referring them to Geitodoris. Since writing this I have examined two other preserved specimens at Plymouth. The back is granulate, with some larger tubercles, and also with some pits, which often give the upper side a honeycombed appearance. The mantle edge is broad, and on the under side veined with anastomosing lines. The branchiæ appear to be nine, and in small 
specimens are very small indeed and hardly visible. There is a distinct labial armature formed of rods, and the radula consists of two kinds of teeth. In the largest specimen the formula seemed to be $25 \times 6+30.0 .30+6$, the six outermost teeth being long, very thin, and compressed together so as to look almost like a single tooth. I have also examined a specimen from Alder and Hancock's collection at Newcastle labelled "Doris planata. W. R. Hughes. Sidmouth." It is only $5 \mathrm{~mm}$. long and 4 broad, and entirely dried up, having unfortunately not been kept in alcohol. As far as anything can be made out under such unfavourable conditions, the external characters are much as in Alder and Hancock's plate. The colour is yellowish, the back granulated and pitted, the mantle edge very ample, the branchial pocket large and round. There is a distinct yellow labial armature composed of rods. As usual in these old specimens, the radula is decomposed and in confusion; but there are clearly visible $(a)$ ordinary hamate teeth; $(b)$ bundles of long, thin, almost shadowy, teeth. The whole animal is very flat.

Through the kindness of Mr. Crossland I have received from the Cape Verde Islands several specimens which are possibly well-grown adults of this form, and in any case are closely allied to it. The general characters, particularly the tentacles, branchiæ, labial armature, and radula (with a formula amounting to at least $10+35.0 .35+10$ ) are similar. The differences are: (1) the size $(50 \mathrm{~mm}$.); (2) the colour, which was in life brilliant vermilion (though some individuals were pale yellow), with numerous black specks apparently visible only under a lens, whereas Alder and Hancock say that $D$. planata was reddish brown, with dark brown spots; and (3) the texture of the dorsal surface, which seems to be covered by a reticulate pattern, with pits between the ridges and flat tubercles at their junctions. But age and a warm climate may account for these differences. However, I have thought it safer to describe the Cape Verde specimens under a separate name as Geitodoris reticulata.

\section{LAMELLIDORIS, A. \& H.}

A considerable number of species are found on the coasts of Great Britain, and seem well characterized externally and by differences in the radula. The Doris beaumonti of Farran (Nudibranchiate Molluses of Ballynakill, app. viii. to part ii. of Report on Fisheries of Ireland for 1901, p. 4) is, no doubt, Lamellidoris luteocincta (M. Sars), which must thus be added to the British fauna.

L. lactea, L. quadrimaculata, L. aureopuncta, $L$. miniata, and $L$. olivacea, described by Verrill from the Bermudas, are all very doubtful forms, 
and in many cases it seems clear from the author's descriptions that they do not possess the characters of Lamellidoris.

In identifying the specimens noticed below as $L$. oblonga, L. depressa, and $L$. pusilla, I have been chiefly guided by the labels which they bear in the collection at the Plymouth Marine Laboratory. I see no reason to doubt these identifications, though it might be difficult to establish them from an examination of preserved specimens only.

\section{LAMELLIDORIS BILAMELLATA (L.).}

This common species has been fully described by Alder and Hancock and Bergh. The back is covered with distinct, tall, and sometimes clavate tubercles, not unlike those of Staurodoris verrucosa. The tubercles at the side of the rhinophores are not conspicuous.

The inner teeth are large, hamate, smooth, and tapering at the tip. The outer are plate-like, with a rudimentary and not very distinct hook. Between the rows there is a series of ear-shaped folds on the rhachis.

\section{LAMELLIDORIS OBLONGA (A. \& H.).}

\section{(A. \& H., Mon. of Brit. Nud., Fam. i., pl. 16, figs, 4-5.)}

Three preserved specimens from Plymouth. It would appear that this species is recognizable by its shape. Its measurements are roughly, length, $8 \mathrm{~mm}$.; breadth, $3.7 \mathrm{~mm}$.; whereas L. bilamellata measures about $12 \mathrm{~mm}$. in length and $9 \mathrm{~mm}$. in breadth. The animal, as preserved, is yellowish, and covered with low, flat tubercles on the dorsal surface. The branchiæ are very inconspicuous, and are not distinguishable from the surrounding tubercles on a superficial examination. The openings of the rhinophores are closed by two tubercles. The rhinophores are exserted and very long. As preserved, the oral veil is remarkably pointed, and the anterior margin of the foot follows its outline.

The buccal crop is large, and divided into two halves by a median band. The radula is very fragile, and consists of twenty-two, thirtythree, and forty-five rows respectively in the three specimens. The inner tooth (Fig. 3. a.) has a broad base, and is divided into three parts by constrictions. The denticulations on the uppermost part are very fine, but clear. The outer tooth (Fig. 3. b.) bears a distinct hook.

\section{LAMELLIDORIS DEPRESSA (A. \& H.).}

One preserved specimen from Plymouth. The mantle margin is wide, and the dorsal surface bears papillose tubercles and contains very long spicules. The colour is yellowish, with a few black and brown spots. 
The radula is small and hard to find. The inner tooth (Fig. 4. a.) is squarish, with three small denticles (not one, as according to Alder and Hancock). The outer tooth (Fig. 4. b.) is a squarish plate with a rudimentary denticle.

\section{LAMELLIDORIS PUSILLA.}

(Alder and Hancock, Mon. Brit. Nud., Fam. i., pl. 13.)

This little species seems to be characterized in life by its white branchiæ and rhinophores.

The radula is somewhat as in $L$. oblonga. The inner tooth (Fig. 5.) has a double convexity at the side, and a few ridges, which hardly amount to denticles, near the tip.

\section{PLEUROPHYLLIDIA.}

PLEUROPHYLLIDIA LOVENI, BERGH.

(Berge, Bidrag til en Monogr. af Pleurophyllidierne, 1866, p. 29 ; Id. Mal. Blätter, 1879, pp. 77-86. Jeffrey's Brit. Conchol., vol. v. pp. 17-18.)

Two specimens from Plymouth. I was informed that the animals were reddish when alive.

The larger is $35 \mathrm{~mm}$. long and $26 \mathrm{~mm}$. broad, tapering rather suddenly at the tail. The colour is dull yellowish brown, with about fifty rather lighter stripes on the back, of which nine are larger than the others. The branchiæ are thin, and about twenty. The side lamellæ about thirty, very thick, and generally interrupted in the middle.

The smaller specimen is much bent, but would be about $30 \mathrm{~mm}$. long if straightened out and 13 broad. The colour is pale yellowish brown, with a sort of purple glazing in many places, and there are about thirty stripes on the back.

The jaws bear five rows of denticles in one specimen and six or seven in the other.

The formula for the radula is in the first $25 \times 35.1 .35$, and in the second $34 \times 32.1 .32$. In both the median tooth bears seven denticles on each side of the central cusp. The first lateral is larger than the rest, and bears six or seven rather coarse denticles. In the larger specimen the first twelve laterals are denticulate (generally with five to six denticles) and the thirteenth very faintly so. The rest are smooth. In the smaller specimen only eleven teeth are denticulate.

It would appear that the Pleurophyllidia found on the British coast is this species, and not $P$. lineata, as it is often described. Bergh also appears to have shown that the correct name of the Mediterranean species is $P$. undulata, not $P$. lineata, and the latter specific name should be cancelled. 
$P$. loveni seems to differ from $P$. undulata in its colour, in having fewer and thicker side lamellæ, and in its dentition. In $P$. undulata the central tooth is much broader, and all the teeth, with the exception of the last two or three in each row, are denticulate.

\section{LOMANOTUS, VÉRANY, 1846.}

(Alder and Hancock, Monograph, Fam. 3, genus 10 (under name of Eumenis). Garstang, Journ. Mar. Biol. Assoc., vol. i., 1889, pp. 185-9. Beaumont, Proc. Royal Irish Acad., 1900, pp. 842-4.)

The members of this genus are not common, and large specimens are distinctly rare, though small ones are not infrequent in some localities, e.g. Plymouth. The body appears to be very delicate and easily torn, and most authors report that their specimens were badly preserved. The following species have been described.

1. Lomanotus genei, Vérany. Catal. degli. anim. invert. di Genovae e Nizza, 1846.

2. L. hancocki, Norman. Ann. Mag. N. H., vol. xx., 1877, p. 518.

3. L. portlandicus, Thomps. Ann. Mag. N. H., 1860, vol. v. p. 50.

4. L. eisigii, Trinch. Rendic. Acc. Sci. Fis. Mat., xxii. 3, 1883, pp. 92-4.

5. L. flavidus, A. \& H., Monograph, Fam. 3, pl. 41.

6. L. marmoratus, A. \& H., Monograph, Fam. 3, pl. 1.

7. L. varians, Garstang, l.c.

Of these names the last is proposed by Garstang for all the British species (L. marmoratus, L. flavidus, L. portlandicus, and L. hancocki), on the supposition that they are really one. But if that supposition is correct, the right course would seem to be not to introduce a new name, but to call all the forms by the earliest of the existing specific names. L. varians may therefore be omitted from the list. The remaining six forms may be divided into the large and the small. Of the large forms $L$. genei has undoubted priority as a name, and it is unfortunate that the authors of the remaining three large species, $L$. hancocki, $L$. portlandicus, and $L$. eisigii, did not, in describing them, state definitely in what points they considered them to differ from the typical species. It seems certain that the number of processes on the frontal veil and on the rhinophore sheaths differs in otherwise similar individuals and cannot be made a specific character. L. portlandicus does not seem to be distinguished from $L$. genei (1.c.) by any clear character. Norman states that the most marked character of his $L$. hancock $i$ is " the small size of the terminal, simple, conical process, which is projected beyond the calyx-like sheath" of the rhinophores. But it is highly probable that the rhinophores were of the usual type, and that the lower laminated portion was merely hidden within the sheath. Trinchese (l.c.) has 
given a somewhat detailed description of $L$. eisigii, from which it appears that its most remarkable characters are: (1) that the hepatic diverticula do not extend into the marginal papillæ; and (2) that the two margins unite at the end of the body and form "una larga pinna che è l' organo principale del nuoto." But a similar organ is found in the specimen described below, and is figured in some unpublished drawings of $L$. portlandicus made by Hancock, and preserved in the Newcastle Museum. Alder and Hancock, as well as Bergh, found the hepatic diverticula in the papillæ, but I could not demonstrate their existence with certainty in the specimen which I examined. It is possible that different specimens may vary in this respect, as do Dendronotus and Bornella excepta. Trinchese also states that in the young L. eisigii, "Ogni papilla conteneva un lobo epatico bene sviluppato."

The small species are L. marmoratus and L. flavidus, both British. With regard to these the main question is, have they assumed their adult and final form, or are they immature? Trinchese states that the young of $L$. eisigii differs markedly from the adult; and if we recognize the possibility of modifications occurring during growth, it may be said that the two small species present no characters either externally or in the buccal parts which are incompatible with the idea that they are the young of $L$. genei. On the other hand, if they are mature (on which point the evidence is inconclusive), the differences in size and colour are, no doubt, sufficient specific characters. A further question is whether L. marmoratus and L. flavidus are distinct forms. If they are adults, they must certainly be regarded as separate species. But if they are immature, then considering that $L$. flavidus is smaller than $L$. marmoratus, and that Trinchese states that the young $L$. eisigii is æolidiform, it is probable that $L$. flavidus is the youngest stage of the same species. Alder and Hancock note the æolidiform characters of the type specimen.

As mentioned below, Alder and Hancock's published plates of $L$. marmoratus are wrong in representing the dorsal margin as continuous with the oral veil, and the error does not occur in an earlier drawing preserved at Newcastle.

I recognize provisionally three species :-

1. L. genei, Vérany.

$=$ L. portlandicus, Thomps.

L. hancocki, Norman.

L. eisigii, Trinchese.

2. L. marmoratus, A. \& H.

3. L. flavidus, A. \& H.

It is, however, highly probable that both of these latter will prove to be young forms of the first, 


\section{LOMANOTUS GENEI, VÉRANY.}

(Bergh, Beitr. zur Kennt. Aeolidiaden, vi. pp. 5-8, and vii. 62-3. Vayssière, Moll. Opisth. de Marseille, part iii. 87-91. Gamble, Ann. Mag. N. H., ser. 6, vol. ix., 1892, p. 379.)

One large specimen from Plymouth Sound, kindly given me by Mr. W. I. Beaumont.

The colour of the preserved specimen is yellowish white suffused with brown, which is deepest on the pericardium, rhinophores, oral veil, mantle margin with papillæ, and on the tail. There are no white dots. Some, but not all, of the papillæ have colourless transparent tips.

The length is $26 \mathrm{~mm}$, the breadth at most 8 , and the height 9, including the raised margin. This margin starts from the rhinophore sheaths and is $2-3 \mathrm{~mm}$. wide. It bears thirty-two papillæ on the right, and thirty on the left side, and is bent into six undulations, three upwards and three downwards. The largest papillæ are those in the centre of these undulations and are about $4 \mathrm{~mm}$. high; the rest are about half the size. The papillæ (Fig. 6) are distinctly spoon-shaped, the convex surface being generally outside, but sometimes inside. At the base of the larger papillæ are two folds on the inside. The margin is entire round the tail and forms a horizontal fin. The anus is $15 \mathrm{~mm}$. from the anterior end, and the genital orifices $6 \mathrm{~mm}$., just behind the rhinophores. The oral veil bears four distinct digitations, two on each side, about $2 \mathrm{~mm}$. long. The rhinophore sheaths are about $3 \mathrm{~mm}$. high; the right bears five digitations; the left, though apparently uninjured, has only one. The foot is produced into short pointed angles and grooved. The upper lamina is much stronger and thicker than the lower.

The jaws are yellow, rather soft and flexible, and much as described by Bergh. The edges for some distance inwards are covered by a mosaic of plates or scales with denticulate edges (Fig. 8.). The masticatory process is very short.

The radula corresponds in general with the descriptions of Bergh and Vayssière. It consists of thirty-two rows. The teeth are large, crowded, and yellow at the sides of the rows; smaller, spaced, and colourless in the centre. In this specimen, and in all the smaller ones observed, the radula has a great tendency to break and become confused, and it seems impossible to spread it out evenly. It is hard to say whether there is a central tooth or not, as the arrangement appears to be not quite symmetrical. Down the rhachis run four to five irregular and not quite straight rows of very irregularly shaped teeth (Fig. 7. a.), bearing a central cusp and three to seven pointed denticles of various sizes on either side. To the right and left of these teeth the rows be- 
come more regular, and there come about ten colourless dagger-like teeth (Fig. 7. b.), with from four to ten fairly regular denticles on either side, the number of denticles increasing as the teeth are further from the rhachis. After this the teeth, as one goes outwards, become larger, yellower, hollowed, and somewhat spoon-shaped (Fig. 7. c.), bearing on either side at least twenty-five denticles, which are shorter and blunter than those of the middle teeth. The outermost teeth of all are somewhat smaller.

The internal organs are not easy to unravel, all the tissues being very thin, soft, and easily torn. The œsophagus leads into a round stomach, which gives off branches (apparently two) at the sides, and is prolonged posteriorly in a diverticulum reaching nearly to the end of the body. On this lie the liver and the hermaphrodite gland, which are both yellowish and difficult to separate from one another. The whole mass is surrounded by a network of transparent tubes, which seem to represent the kidney. The dorsal papillæ are hollow and communicate with the interior of the body, but I could not satisfactorily demonstrate the existence of branches of the liver in them (cf. what Trinchese says about $L$. eisigii). If such exist, they are represented by floceulent masses of no very definite shape, composed of reddish cells. The mucus and albumen glands are large; the ampulla of the hermaphrodite gland long and thick; the vas deferens thinner and coiled; the penis conical and unarmed; the spermatotheca small and roundish.

If any real distinction can be drawn between $L$. genei and $L$. eisigii, this animal should probably be referred to the latter in virtue of the shape of the papillæ and the apparent absence of hepatic diverticula in them. But I do not think that the two species are really distinct.

\section{LOMANOTUS MARMORATUS, A. \& H.}

Four living specimens (A) examined at Plymouth in April, 1905, were about $9 \mathrm{~mm}$. long and $2 \mathrm{~mm}$. broad. The ground colour of the living animals is yellowish white, but largely covered with irregular markings of different shades of brown and olive, and also with small sandy dots. The colour is darkest at the sides and lighter in the centre of the back. The tips of the cerata are whitish; the hepatic diverticula within them yellowish brown.

The foot is cleft, and indented in front with strongly hooked corners. The veil is not large, with four processes, two on each side, which are somewhat bulbous at the tip. The rhinophore sheaths are rather tall for the size of the animal, being about $2 \mathrm{~mm}$. high, and bear four or five processes, the number not being always the same on the right and left sheaths. In one specimen one sheath is entirely smooth. The 
dorsal margin starts from the rhinophore sheath; it makes four not very distinct undulations and bears about twenty-two papillæ, most of which, especially the taller ones, are carried vertically, though some of the smaller ones point sidewards. The taller papillæ bear a distinct bulb under the pointed tip, but in the smaller ones the bulb is less developed. Four of the papillæ are distinctly larger than the rest and, roughly speaking, mark the divisions between the undulations. The third of these larger papillæ is the tallest of all and is about $2 \mathrm{~mm}$. high (Fig. 9. c.).

Another specimen (B), which was about $7 \mathrm{~mm}$. long when at rest and $8 \mathrm{~mm}$. when crawling, was brownish white, with yellowish-brown mottlings down the centre of the back and deep purplish-brown mottlings on the cerata. The other external characters are much as in the specimens already described, but the papillæ are not so long and there are only obscure indications of the subterminal bulb. The dorsal margin is more clearly a web connecting the papillæ. The rhinophore sheaths bear five processes each.

Three other specimens of about the same size were so macerated that nothing could be done with them except to examine the buccal parts.

The jaws and radula are much the same in all eight specimens. The jaws are not denticulate, but near the edge is a mosaic formed of tilelike prominences denticulate on the anterior edge. The radula is very irregular in appearance and could not be laid out straight in any specimen. There is a wide naked rhachis bearing folds, and on each side of the rhachis fifteen to twenty rows of teeth, each containing eight to ten teeth on either side. More could not be made out with certainty. The teeth are longer than in Alder and Hancock's and Bergh's plates, and more uniform. They are dagger-shaped, but slightly bent at the end, bearing at least twelve denticles on either side and perhaps considerably more, but the denticles are hard to see, even with a high power. The innermost are slightly shorter and stouter; the outermost longer and thinner.

The animals are very delicate. They die in captivity without apparent cause, and the body becomes decayed and macerated very rapidly.

This form, especially the specimen called B, approaches the $L$. marmoratus of Alder and Hancock sufficiently nearly to bear the name. Their plate (Eumenis marmorata, Fam. 3, pl. 1. a.) contains one of the few inaccuracies to be found in their works, inasmuch as it represents the dorsal margin as continuous with the oral veil, not as starting from the rhinophores. But in a preliminary study for the drawing preserved in a bound volume of Alder's drawings, belonging to the Hancock Museum at Newcastle-on-Tyne, the disposition of the parts is somewhat 
indistinct, and it is quite probable that it was meant to represent the dorsal margin as starting from the rhinophores. When this study was copied for the plate as published, the artists themselves probably misinterpreted their earlier and rather indistinct drawing. But I do not think that we should insist that the continuity of the dorsal margin and oral veil is really a character of $L$. marmoratus, A. \& H.

\section{LOMANOTUS FLAVIDUS, A. \& H.}

A single small specimen examined alive at Plymouth resembled Alder and Hancock's figure of this species. It is only $4 \mathrm{~mm}$. long and $1 \mathrm{~mm}$. broad. The general colour is pale buff, due to a multitude of little specks. There are also white spots (particularly on the tops of the cerata) and a few purplish-brown spots. At the sides of the head in front of the rhinophores are two purplish-brown patches. The rhinophore sheaths bear five processes, of which the one behind and pointing outside is longer than the others. There are only about twelve papillæ on each side. They are much as in Alder and Hancock's plate-short, thick, and showing no signs of a bulb. Those in the middle are the largest. They mostly have an irregular brown ring or marking.

The animal is not like $L$. marmoratus superficially, but no difference could be found in the buccal parts. The foot, veil, and other external characters not mentioned above are also similar.

\section{HANCOCKIA, GOSSE.}

$$
=\text { GOVIA, Trinchese. }
$$

Bergh (System der Nudib. Gast., p. 1048) adopts Govia (Trinchese, 1886) as the name of this genus in preference to Hancockia (Gosse, 1877), apparently on the ground that Gosse's description is inadequate. But though Gosse does not deal with the anatomy of the animal, his description is amply sufficient for its identification. There can be no reasonable doubt that his Hancockia dactylota is the animal described below, and that it is generically and perhaps specifically the same as the later Govia of Trinchese. The name is therefore entitled to stand.

The genus appears to be rare, and is recorded from the south of England, Brest, and the Mediterranean. Four described species are probably referable to it: Hancockia dactylota, Gosse; Govia rubra, Trinchese; Govia viridis, Trinchese; ${ }^{*}$ and Doto uncinata, Hesse. In the Jour. de Conchyl., 1872, p. 34, Hesse described under this name a Nudibranch captured at Brest, but Garstang seems to have proved that it is a Hancockia. Whether there is really more than one species is a

\footnotetext{
* References to the literature are given on following page.
} 
matter of some doubt. Perhaps Trinchese's two species are distinct, and perhaps his Govia viridis is identical with both Doto uncinata and Hancockia dactylota, so that the genus may be tabulated as follows:-

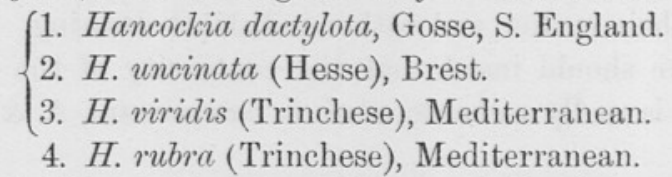

Hesse regarded his specimen as a Doto, and Bergh somewhat doubtfully refers the genus to the Dotonidæ. It would seem to be intermediate between that family and Lomanotus. The narrow radula indicates affinity to Doto and the true Eolids. The cerata show analogies to those of Doto, though they have not their characteristic shape. But the perfoliations on the rhinophores, the processes on the oral veil, and the manner in which the cerata arise from the dorsal margin recall the characters of Lomanotus rather than of Doto.

\section{HANCOCKIA DACTYLOTA, GOSSE.}

(Gosse, "On Hancockia dactylota," Ann. Mag. Nat. Hist., ser. 4, xx., 1877, pp. 316-19. Gamble, "On two rare British Nudibranchs, Lomanotus genei and Hancockia dactylota," $i b ., 6$, ix., 1892, pp. 378-85. Trinchese, "Ricerche anatom. sul genere Govia," Mem. della $R$. accad. delle sci. dell" istituto di Bologna, ser. 5, vii. pp. 183-91, 1886. Bergh, System der Nudib. Gast., p. 1048, 1892, sub voce Govia.)

Two specimens labelled "Plymouth district, Sept. '97 and '98." They are of much the same size, one being rather more elongate than the other. Measurements in millimetres :-

$\begin{array}{ccccc}\text { Length. } & & \text { Breadth. } & & \text { Height. } \\ 7 & \ldots & 1 \cdot 2 & \ldots & 2 \\ 6 & \ldots & 1.5 & \ldots & 2\end{array}$

The colour is greyish green, and the shape rather stiff and rectangular. The animals are not very well preserved either externally or internally; but a small specimen subsequently given me by Mr. Allen proved to be in better condition and was sectioned.

The foot is truncate in front; no groove is visible on the anterior margin; the tail is not pointed behind, and is slightly bifid.

The oral veil is smooth in the middle and curves inwards, but the two sides are much expanded and each bears four digits, of which the second from the inside is the longest. The rhinophore sheaths, which are set on the dorsal margin, are about $1 \mathrm{~mm}$. high and $5 \mathrm{~mm}$. broad, straight, cylindrical, not expanded at the top, but divided into eight to ten low lobes. The upper part of the rhinophores is a smooth column; at the base are a few obliquely vertical perfoliations. From the rhinophore sheaths runs backwards a not very distinct marginal ridge, on 
which are set five processes on the left side and four on the right. The processes in the first pair are opposite one another. Then they gradually become alternate. They bear lobes with a rather irregular outline, so that the whole process looks like a short, thick branchial plume. The first pair have eight lobes, four on each side, and are folded along the median line, the concave surface being turned outwards. The second, third, and fourth pairs are similarly folded, but bear only seven lobes, three on each side and one terminal. The fifth process (found on the left side only) has five lobes and is irregular in shape. The genital orifices are close to one another, on the flank of the body, between the rhinophores and the first process. The vent is between the first and second processes, close to the dorsal margin.

The nervous system is yellowish. The ganglia are hard to separate, but as seen from above appear to be as described by Trinchese. The cerebro-pleural ganglia are large and triangular, showing no sign of division. The pedal ganglia, which are smaller, lie at their side on a lower level. The buccal ganglia are large. The eyes are large and of an intense bluish black.

The jaws bear a row of distinct but irregularly shaped denticles on the masticatory process. Higher up on the jaw itself there seem to be numerous projections near the edge. The radula resembles that of Galvina, and consists of thirty-one rows of three teeth each. The median teeth (Pl. XI., Fig. 10. a.) are very strong and distinct, with four well-developed denticles on each side of a large raised median cusp. The laterals (Fig. 10. b.) are very thin and hard to see, but are much as in Galvina, broad, but with a sharply pointed summit.

The animals being small and indifferently preserved, it was difficult to make out the digestive system by ordinary dissection, and the following details are derived almost entirely from the specimen which was sectioned. A fairly long osophagus (Pl. XII., Fig. 11. a.) leads from the buccal mass to the stomach and gives rise about midway to a curved diverticulum (Fig. 11. b.). The stomach (Fig. 11. c.) is roundish and not very large. From the top of it rises the intestine (Fig. 11. d.), which sends out a tube to the anal papilla (Fig. 11. e.) on the right. The anterior lower part of the stomach is prolonged into two diverticula (Fig. 11. f.), which supply the first pair of cerata and then run straight forward, terminating in the anterior part of the foot. The termination is trifid. Posteriorly the stomach gives rise to a long and fairly wide tube (Fig. 11. i.), which extends to the hinder part of the body and sends off branches (Fig. 11. g.) to the cerata. These branches are at first simple, but before they enter the cerata they divide into as many ramifications (Fig. 11. h.) as there are lobes to supply. These secondary ramifications arise at different levels. At their termination they open externally by 
orifices (Pl. xII., Fig. 13. e.) which appear to be cnidocysts. They consist of a fairly broad tube, which is narrowed by a constriction when it reaches the integuments and forms outside the constriction a cup-shaped aperture. There are traces of similar openings on the anterior margin of the foot; but it is unusual to find cnidocysts in this position, and the structure of the organ is not clear. Abundant mucous glands are scattered over the whole surface of the body, and the mucus can be seen under the microscope in the act of exuding.

The hermaphrodite gland (Pl. XII., Fig. 12. 1, n.) is large and fills all the posterior part of the body cavity with large yellowish packets. The anterior genital mass is also well developed, but hardened and not well preserved. No trace of armature was found, and the spermatotheca appeared to be surrounded by the albumen gland.

\section{DOTO, OKEN.}

A considerable number of species have been referred to this genus, but it is greatly in need of a revision based on a study of a large series of living animals. The internal characters offer few points of difference, and the external characters, such as coloration and the shape of the rhinophore sheaths, are somewhat variable, and liable to be either distorted or obliterated in preserved specimens. Bergh, in his System der Nudib. Gast., registers sixteen species, described chiefly by Alder and Hancock, Hesse, and Trinchese. Of these it would appear that $D$. arbuscula, Agassiz, and D. minuta, Forbes, are mere names. D. australis, Angas, is perhaps a Melibe and not a Doto at all, and the later D. ocellifera of Simroth (Die Gasteropoden der Plankton Expedition, 1895, pp. 168-70) is of very doubtful affinities. The forms which probably belong to the genus may be enumerated as follows :-
1. Doto coronata (Gm.).
10. D. cinerea, Trin.
2. D. formosa, Verrill.
11. D. pinnatifida (Mtg.).
3. D. cuspidata, A. \& H.
$=D$. splendida, Trin.
4. D. fragilis (Forbes).
12. D. paulince, Trin.
5. D. crassicornis, M. Sars.
13. D. indica, Bergh.
6. D. cost $\propto$, Trin.
14. D. africana, Eliot.
7. D. cornalia, Trin.
8. D. rosea, Trin.
15. D. floridicola, Simroth.
9. D. aurea, Trin. perhaps = Dotilla (?) pygmoea, Bergh. 16. D. annuligera, Bergh.

\section{DOTO PINNATIFIDA (MONT.), VAR. PAPILLIFERA.}

Three specimens from Plymouth, nearly a centimetre long. The coloration, cerata, etc., seem typical of the species as described by Alder and Hancock, but there are numerous papillæ on the back, each with 
a black spot at the tip; and there are two or in some places three rows of such papillæ on the sides. The rhinophore sheaths are ample in front, but slit behind, and bear two or three papillæ (Fig. 14.). All these papillæ are too much developed to be called tubercles, and are half or even three-quarters of a millimetre in height. The anal papilla is very large.

The buccal mass is very small and the radula minute, though it contains more than 100 closely fitting teeth. The teeth bear at least three denticles on each side of the central cusp and perhaps other accessory denticles and ridges; but it is difficult to get a distinct view of any tooth, even under the highest power.

This form is probably a variety of $D$. pinnatifida with the tubercles more developed. All the proportions of the animal are larger than those described by A. \& H., and it is possibly merely the normal adult form.

\section{BERGHIA CCRULESCENS (LAURILLARD).}

The specimen preserved at Plymouth under this name is really a Facelina coronata, and has neither the rhinophores nor the dentition of Berghia. Berghia should probably be removed from the list of the British fauna, as there appears to be no other record of its occurrence.

The cerata are set in eight groups. At the interior end of several of them (that is at the sides of the clear space in the middle of the back) are a number of quite small tubercular papillæ, hardly half a millimetre high, and similar ones are found here and there in the middle of the rows. These tubercles probably represent cerata which have been bitten off and are in process of reproduction. See Bergh, Beiträge zur Kenntniss der Elidiaden, v. p. 826. Alder and Hancock mention that the animals of this species ( $F$. coronata) have the habit of eating one another's cerata.

\section{ÆOLIDIELLA, BERGH.}

EOLIS ANGULATA, A. \& H.

I think that the Eolis angulata of Alder and Hancock (Monogr., Fam. 3, pl. 23) is really referable to this genus, and merely a broad and probably immature specimen of Eolidiella glauca. Professor Herdman kindly gave me a specimen from Port Erin in the Isle of Man which was identified by him when alive as possessing the external characters of Eolis angulata. The preserved specimens also seemed to have these characters, as far as they could be recognized, except that the cerata were more numerous. When dissected it was found to possess the jaws and characteristic radula of AEolidiella glauca. 
If this specimen is really Alder and Hancock's Eolis angulata, I do not think that species can be separated from AEolidiella glauca. As shown in Alder and Hancock's plates the coloration and general appearance are much the same, and it is noticeable that in both the rhinophores are represented as showing indications of slight annulation. Since Eolis angulata was four lines long and Eolidiella glauca nearly two inches, differences in shape and the number of cerata cannot be regarded as safe specific characteristics.

The anatomy of Ailidiella glauca is described by Bergh in his Beitr. zur Kenntn. der AEolidiaden, viii., 1885, pp. 24-8. The known distribution of the species extends from Scandinavia to the Mediterranean.

\section{CORYPHELLA.}

This genus consists of Eolids, with a triseriate radula, somewhat elongate bodies, and unperfoliated rhinophores. It is noticeable, however, that in several species the rhinophores show traces of rings or wrinkles, or bear minute lumps. The details submitted below seem to show that $C$. gracilis and $C$. smaragdina are varieties of one species. C. beaumonti, now first described, offers many peculiarities, and almost merits generic rank.

Bergh in his System der Nudibranchiaten Gasteropoden recognizes twenty-three species, of which several must be regarded as doubtful (e.g. C. alderi, C. parvula, C. semidecora, C. forelisi, C. ocellata), since the radula is unknown. To this list may be added:-

C. cooperi, Cockerell (Jour. of Mal., 1901, viii. 3, p. 85).

C. californica, Bergh (Mal. Unt. in Semper's Reisen, vi. 1, 1904, p. 6).

C. sarsi, Friele (Bergen's Museums Aarbog, 1902, No. 3, p. 12).

Cockerell (J. of Malac., 1901, p. 121) considers Cooper's AEolis iodinea to be a Coryphella, but Bergh refers it to Flabellina. Verrill's Coryphella (?) pallida is somewhat doubtful.

\section{CORYPHELLA RUFIBRANCHIALIS (JOHNST.).}

(Alder and Hancock, Monog. of British Nudib., Fam. 3, pl. 14.)

One living specimen, Plymouth, April, 1905. The animal is very elongate, $15 \mathrm{~mm}$. long and only $3 \mathrm{~mm}$. broad. The foot is produced in front into fairly long tentacular angles, which are very distinctly grooved. The oral tentacles are $5 \mathrm{~mm}$. or more long, and are carried in a curved position. The rhinophores are $7 \mathrm{~mm}$. long, straight, and covered with rows of little lumps set in fairly regular rings. There are about twenty-five rings, and about eight lumps in each. 
The cerata look less thick than in Alder and Hancock's plate. They are slender and cylindrical, but often irregularly constricted near the tips, as if injured. The last two are set medianly on the caudal ridge. The anus is lateral, but high up. The tail not long.

The body is transparent and colourless, with only a very little opaque white on the oral tentacles and rhinophores. The hepatic ramifications within the cerata are of a bright, light scarlet, and somewhat irregular in outline. Above the scarlet is a broad opaque white ring, and above that a pellucid point. There is a faint yellow tinge in the rhinophores and down the centre of the back.

The jaws bear eight to nine rows of irregular denticles. The radula consists of thirteen rows. The median tooth has a strong central cusp, and seven rather long and thin denticles, curving slightly inwards. The side teeth bear twelve longish slightly curved denticles. Alder and Hancock (Tongues of the Eolidida) say that the apex of the side teeth points outwards, but this did not seem to be the natural position in the present specimen, though the teeth are easily displaced.

In spite of this and some other small points of difference, I think this specimen must be referred to $C$. rufibranchialis. It can hardly be C. pellucida, which it also resembles, as that animal is said to have smooth lateral teeth.

\section{CORYPHELLA GRACILIS (A. \& H.).}

One living specimen, Plymouth, April, 1905, $6 \mathrm{~mm}$. long, and rather elongate. The body is of a not very transparent white, with a good deal of opaque white, especially on the oral tentacles, rhinophores, and tail. The cerata have opaque white pigment at the top, which sometimes, but not always, forms a distinct ring. The hepatic diverticula are of a reddish orange. The anterior angles of the foot are produced, but are not very long. The oral tentacles are distinctly longer than the rhinophores, which are smooth. The cerata are rather thick and elliptical, and are set in four groups, containing on each side eight, five, five, and three cerata respectively.

The radula consists of eleven teeth. The central tooth bears four to six (generally five) denticles on each side of the median cusp. The laterals bear six denticles.

This appears to be a fairly typical specimen of C. gracilis. Alder and Hancock say it has four denticles on the central tooth, Bergh that it has five.

Another living specimen seen at Plymouth at the same time was $9 \mathrm{~mm}$. long and 2.5 broad. It was very active, and fond of swimming foot uppermost.

The tail is long; the anterior angles of the foot are produced into 
distinct but short horns. The oral tentacles are moderately long, with a few scattered opaque white dots. The rhinophores are long, wrinkled, but not perfoliate, transparent and colourless, except that the tips are covered with opaque white dots. The eyes are small, but black and distinct. The cerata are set in five groups, composed on the right side of three, four, two, four, three, and on the left of three, three, four, two, three cerata respectively. These five groups are all seen to be distinct when the animal is moving and stretched out. Otherwise the first and second and the fourth and fifth appear to coalesce, though the third always remains distinct. The general impression produced is that the cerata are few and scattered irregularly. The innermost are the largest and are rather swollen. The body is colourless and transparent. On the tail is a line of irregular bright white spots. The yellowish-grey hermaphrodite gland can be seen through the integuments. The hepatic diverticula within the cerata consist of two elements, one bright green, the other brownish yellow. As a rule the green predominates and gives the general colour, but in some of the cerata the brown pigment prevails.

The jaws are thin and colourless, with at least six rows of denticles. The radula consists of thirteen rows. The central tooth has as a rule four denticles on each side of the median cusp, but sometimes five, and only once six. The laterals have the apex turned inwards and bear five or six denticles.

A third specimen was dead when examined. Though much macerated and mutilated, it appeared to have resembled the one just described externally. The cerata were green with white tips. The radula consisted of twelve rows. The central teeth have uniformly seven denticles on each side of the median cusp. The laterals bear three to six denticles. The tips of several laterals seem to point outwards.

According to Alder and Hancock, who created both species, $C$. gracilis has orange-red cerata and four denticles on the central teeth, whereas C. smaragdina has green cerata and seven denticles. The second of the forms described above appears to be intermediate both in colour and dentition between C. gracilis and smaragdina, and suggests that the animals in which the green pigment predominates should be called C. gracilis, var. smaragdina.

Vayssière (Recherches sur les Moll. Opisth. du Golfe de Marseille, ii. p. 76), regards C. landsburghii, C. rufibranchialis, C. pellucida, C. smaragdina, and $C$. gracilis as being all synonyms. This appears to me excessive, as besides other characters the forms vary in their dentition. But it must be admitted that we require much more information to enable us to judge how far the number of denticulations may vary within the limits of one species. 


\section{CORYPHELLA LANDSBURGHII, ALDER \& HANCOCK.}

(Alder and Hancock, Monog. of British Nudib., Fam. 3, pl. 20. Trinchese, Eolidida di Genova, ii., Tav. lxii., lxiv., lxvi.-lxx. Bergh, Die Nudibr. gesanmelt während d. Fahrten d. Willem Barents, p. 8.)

One living specimen, Plymouth, April, 1905. Very slender and elongate, $7 \mathrm{~mm}$. long and only about $1 \mathrm{~mm}$. broad. Cerata nearly $2 \mathrm{~mm}$. long; rhinophores $2.3 \mathrm{~mm}$. long. Foot produced into distinct tentacular angles. Oral tentacles fairly long and slightly wrinkled; rhinophores longer and more distinctly wrinkled. They bear low rings of rather irregular outline, but not perfoliations or knobs. The cerata are set in eight short rows arranged as follows on each side :-

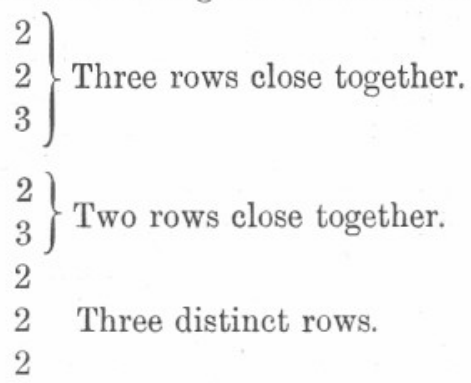

The body, rhinophores, and tentacles are of a clear amethyst, with which the orange-red ramifications of the liver within the cerata form a striking contrast. The cerata bear a ring of opaque white below the pellucid tips. The foot is whitish.

The jaws bear six to seven rows of denticles near the top, but the number decreases lower down. The radula consists of thirty rows. The central tooth is rather broad and arched. It bears five denticles on each side of the central cusp, which is not much larger than the rest. The laterals are of a fair size, but somewhat difficult to see, as they are quite colourless. They have a long apex and five to six small denticles.

This appears to be a fairly typical example of Alder and Hancock's C. landsburghii. They do not mention that the rhinophores are wrinkled, though it is indicated in their plate, and they describe them as distinctly shorter than the oral tentacles, which is not the case here.

The most striking characteristic of this form is its strangely contrasted coloration. It is very doubtful if the specimen from Vardö referred to this species with a query by Bergh (l.c.), really belongs to it.

CORYPHELLA BEAUMONTI, spec. nov.

Mr. W. I. Beaumont, to whom the species is dedicated, has kindly furnished me with the following notes on the living animal.

"Eolid from Barn Pool (Plymouth). Length, 16 mm., but looks as if the 
posterior part of the body had been lost, as it ends abruptly only $3-4 \mathrm{~mm}$. behind the heart.* The outline of the anterior end of the foot is like Eolis nana, except that the sides are produced into small angular projections kept tucked in and consequently inconspicuous. Head nearly as wide as the foot. The oral tentacles very minute; merely short processes of angles of the oral veil. The rhinophores are long and smooth, held erect with tips bent back. The eyes do not show. Papillæ very numerous and extremely long, slender and tapering to fine points, constantly in motion, curling and uncurling, and when at rest convoluted. A group of small papillæ, apparently three rows, is wholly in front of the rhinophores on each side. Then a row on each side abreast of rhinophores. Another row between this and the next, which is abreast of the anterior end of the heart. Then a row level with the posterior end of the heart. The outer ends of the rows are not double.

"The colour of the body is red, tending to orange on the rhinophores, but elsewhere more rosy. The colour seems to be situate in the superficial tissues. The papillæe are superficially flesh-coloured. The hepatic cœca are in most of the papillæ rosy purple throughout, but in a few pale greenish purple, except at the tip, which is rosy purple in all and more deeply coloured than the rest of the organ. The cœea are slender, especially at the distal ends, and much corrugated. The extreme tips of the papillæ beyond the end of the cœca are yellowish flesh colour, deeper than the superficial colour of the rest of the papillæ."

I have examined two preserved specimens given me by $\mathrm{Mr}$. Beaumont, $20 \mathrm{~mm}$. and $14 \mathrm{~mm}$. long respectively. The colour is dead white, not very transparent. The hepatic diverticula are yellowish white and corrugated. The external characters agree with Mr. Beaumont's description. The front of the foot is broad and expanded, but the tentacular angles are small and bent downwards and inwards. The anterior margin is not grooved. Over the mouth is a broad oral veil $(5.3 \mathrm{~mm}$.) expanded into short tentacles $(1.7 \mathrm{~mm}$.) at the sides. The rhinophores are long $(7.5 \mathrm{~mm}$.), thin, not perfoliate, and placed close together on a slight prominence. There are three rows of cerata distinctly in front of them. The cerata are set on eight narrow, curved ridges, which are single and do not form horseshoes. The first three rows are close together, the next three not far apart, but the last two are more distant. In the perfect specimens the length of the cerata obscures this arrangement. There are four to six cerata in each row. The cerata in front of the rhinophores are short, cylindrical, and 2-4 mm. long. The posterior cerata are very long; in the specimen, which has a body $20 \mathrm{~mm}$. long, they measure as much as $15 \mathrm{~mm}$. and are about $1 \mathrm{~mm}$. broad at the base.

* The specimens here described are much the same.-C.E. 
The jaws bear two or three rows of denticles. The radula is triseriate, and consists of twenty and fourteen rows respectively in the two specimens. The central tooth (Fig. 15. a.) has a strong central cusp, which bends slightly downwards, and hence sometimes appears asymmetrical when pressed flat in a slide. On each side of it are a number of small denticles of varying shape and size. The smallest number observed was sixteen and the largest twenty-four. The laterals (Fig. 15. b.) are also broad, with slightly lower cusps, and twenty to thirty accessory denticles on the inner side. No denticles were visible on the outer side of the laterals.

The penis, which is partially protruded in one specimen, is sickleshaped and very deeply grooved, consisting of a lamina folded down the middle and probably capable of assuming a foliaceous expansion. This part is unarmed, but the base of the penis and the end of the spermatic duct bear numerous yellow cones (Fig. 16.) terminating in a short bent appendage. They appear to be soft and not spiculous or chitinous. The spermatotheca is large and spherical.

As this species has smooth rhinophores and the radula of Coryphella, I provisionally refer it to that genus in order to avoid multiplying genera. But in many of its characters-such as the shortness of the oral tentacles, the length of the cerata, the position of some of the cerata in front of the rhinophores, and the conformation of the penisit differs markedly from the described Coryphellæ, and it may ultimately prove better to make it the type of a new genus.

\section{CRATENID压, BERGH.}

(Bergh, Mal. Unt. in Semper's Reisen, Heft i., 1870, pp. 1-4, and Heft xviii. pp. 1021-4. Beaumont, "Fauna and Flora of Valentia Harbour," in Proc. Royal Irish Acad., 1900, pp. 834-8. Friele, "Mollusken der ersten Nordmeerfahrt," Bergen's Museums Aarbog, 1902, No. 3, p. 9.)

As the authors cited above observe, Bergh's classification of this group raises many difficulties in practice, on account of the minuteness of the generic distinctions and the doubt whether the forms really possess the characters which he attributes to them. He divides the subfamily into five genera-Cuthona, Cuthonella, Cratena, Hervia, and Phestilla. Of these the last named differs from the others in several particulars. Hervia also may be set aside as characterized by the corners of the foot being prolonged into tentacular processes. It is not recorded from British waters, though as the habitat of one species is the Northern Atlantic it may some day be added to our fauna. The other three genera, Cuthona, Cuthonella, and Cratena, are closely connected, and to them must be added in my opinion Amphorina. Bergh classes 
Amphorina under the Galvinidæ, which hardly form a natural subfamily, the only character common to the component genera being that the cerata are more or less inflated. In Amphorina this feature is not very marked, and its other characters ally it to Cratena. The tropical genera Zatteria, Myja, and Ennoia are also probably allied, but need not be considered here.

With regard to nomenclature, Bergh appears to have proved that the names Cavolina and Montagua must be rejected.

The animals which compose the four genera Cratena, Cuthona, Cuthonella, and Amphorina are small and inconspicuous, though often beautifully coloured. The rhinophores are not perfoliate, the corners of the foot are not developed into tentacular processes, and the radula is uniseriate. There is an absence of any very striking characteristics either internal or external. The most distinct genus is Amphorina. It has slightly inflated cerata, a style on the penis, and a long tapering radula containing from fifty to eighty teeth, which gradually increase in size. The denticles on the teeth, particularly the median cusp, arise far back, and hence have a peculiar elevated appearance. To this genus at least the following species must, in my opinion, be referred :-

1. Amphorina alberti, Quatrefages.

2. A. coerulea (Mtg.).

3. A. molios, Herdman.*

4. A. aurantiaca (A. \& H.) = Cuthona aurantiaca.

5. A. olivacea (A. \& H.) = Cratena olivacea.

Perhaps Cratena viridis will prove to be an Amphorina, as may also E. glottensis. In separating the other genera Bergh makes use of the structure of the auditory capsule, which he says contains a single otolith in Cuthona, but several otoconia in Cuthonella and Cratena. Beaumont, however, denies this, and reports the existence of single otoliths in species classified by Bergh under Cratena (e.g. Cr. amona). In any case, the character is so minute and so difficult to determine in preserved specimens that it seems undesirable to use it, unless absolutely necessary. Setting aside possible differences in the auditory capsule, it would appear that the only clear distinction between Cuthona and Cratena formulated by Bergh is that the head is broad in the former, but not in the latter. This character seems to be clear and conspicuous, though, as it is merely a question of degree and development, one may doubt if it is really of generic value. If it is accepted, it would appear that the following are referable to Cuthona:-

1. Cuthona nana, A. \& H.

2. C. pumilio, Bergh (Sargasso Sea).

${ }^{*}$ I agree with Mr. Beaumont (l.c.) in thinking that the specific distinctness of this species from $A$, cerulea is doubtful, 
3. C. bicolor, Bergh (Japan).

4. C. peachii, A. \& H. (see Beaumont, l.c.).

Eolis inornata, A. \& H., and Cuthona stimpsoni, Verrill ("Addns. to Marine Fauna of N. America," in American J. of Sci. and Arts, vol. xvii. p. 314,1879 ), possibly belong to this group, but are imperfectly described, and the buccal parts unknown.

The genus Cuthonella was founded by Bergh for a single specimen obtained by the Challenger in the Faroë Channel. Like Cuthona it has a broad head, but it differs from both Cuthona and Cratena in having the foot truncated in front, jaws armed with several series (not a single series) of denticles, and the anus opening on the back, not on the side. It will be seen that all these characters, except the last, are very slight. Friele (l.c.) examined specimens from the North Atlantic which had the general characters of the Cratenidae and a dorsal anus, but a rounded foot and a rather irregular denticulation of the jaw. Not wishing to create a new genus for these trifling deviations, he referred the form to Cuthonella, the characteristic of which thus becomes the position of the anus, which is dorsal, but somewhat to the right of the median line.*

The genus thus contains-

1. Cuthonella abyssicola, Bergh.

2. C. ferruginea, Friele.

3. C. berghi, Friele.

All from the North Atlantic, but not from British waters.

There remains the large genus Cratena, in which can be included most of the forms not assigned to Cuthona, Cuthonella, and Amphorina, though some of the less-known species of this group, such as Eolis northumbrica, present remarkable peculiarities. In Cratena the head is not broad, the cerata are not inflated, and the anal papilla is on the side, not on the back. The radula is generally (but not always) short and not markedly tapering. The teeth bear a few (rarely more than ten) denticles on each side of a central cusp which is often not prominent. As a rule the penis is unarmed, but in some cases, for which it hardly seems worth while to create a new genus, it bears a style. The following species seem referable to this genus with more or less certainty :-

1. Cratena hirsuta, Bergh. Greenland.

2. Cr. olrikki (Mörch). Greenland.

3. Cr. pustulata (A. \& H.).

4. Cr. amona (A. \& H.).

5. Cr. fructuosa, Bergh. Sargasso Sea.

* I understand this to be the case in Cuthonella abyssicola, but Bergh's statenents in the Challenger Report, on p. 24 and p. 25, are not quite consistent, 
6. Cr. concinna (A. \& H.).*

7. Cr. pilata (Gould). North-West Atlantic.

8. Cr. bylgia, Bergh. Philippines.

9. Cr. longibursa, Bergh. Pelew Islands.

10. Cr. stipata (A. \& H.).

11. Cr. cavances, Bergh. Chile.

12. Cr. pusilla, Bergh. Juan Fernandez.

13. Cr. cucullata, Bergh. Malay Archip.

Cr. viridis (Forbes) and Cr. glottensis are probably Amphorinas, and it seems difficult to separate Cratena gymnota (Gould) from Amphorina aurantiaca. Cr. arenicola (Forbes), Cr. veronicae (Verrill), Cr. couchii (Cocks), and Cr. purpurascens (Fleming) are imperfectly described. Cr. cingulata is placed by Alder in Jeffrey's Conchology, vol. v. p. 53, under Galvina, which implies that it has a triseriate radula. Cr. lugubris, Bergh, is referred to this genus with a query by the author himself.

In Jeffrey's Conchology, vol. v. p. 45, etc., Alder distributes the British forms between Cuthona and Cavolina. The former, which is defined as having the branchiæ close set and a uniseriate radula with a central spine and lateral denticulations, includes C. peachii, C. nana, C. stipata, C. angulata, C. inornata, C. concinna, C. olivacea, C. aurantiaca, and C. pustulata. Cavolina, which is defined as having the branchiæ set in rather distant rows and a uniseriate denticulated radula with the central spine a little prominent, includes C. couchii, C. amoena, C. northumbrica, C. arenicola, C. glottensis, C. cerulea, C. viridis, and C. purpurascens. Though something may be said for this division, it ignores the existence of Amphorina (Quatrefages, 1844), and the point on which stress is laid-whether the branchiæ are close set or in distant rows-is often difficult to determine in preserved specimens, and might be doubtful in living ones.

In the above remarks I have merely considered how the described species can be most naturally distributed among the described genera. Whether those genera are valid and necessary is another question. I doubt myself if Bergh's whole subfamily of Cratenidæ, including Amphorina (but perhaps excluding Phestilla) offers more than one good generic type; and if nature provides a great number of similar forms it seems unscientific to separate them into many genera on the strength of small points of difference. It is convenient, no doubt, to divide a large genus into sections or subgenera, but to split it into several genera if the differences between them are of less than ordinary generic value obscures the real uniformity of the animals classified.

* Cr. concinna. Since writing the above I have had an opportunity of examining a specimen of this species from the Menai Straits, given me by Prof. Herdman. The characters agree with A. \& H.'s description. No style was found on the penis. The teeth of the radula are remarkably long, narrow, and pointed. 


\section{AMPHORINA AURANTIACA (A. \& H.).}

(Alder and Hancock, Mon. Brit. Nud., Fam. 3, pl. 27.

Beaumont, l.c., pp. 836-7.)

One living specimen examined at Plymouth, April, 1905. The animal, which was active and seemed to resent being touched, measured $8 \mathrm{~mm}$. in length and 3.5 in breadth when extended. Mr. Beaumont observes that specimens as highly coloured as Alder and Hancock's plate are rare, and the present one was decidedly less brilliant. The tentacles and rhinophores were colourless, the latter with a faint red tinge. The body was colourless and transparent, with very minute, hardly visible opaque white dots. Behind the black eyes was a reddish spot, possibly caused by some internal organ showing through the skin. The general effect of the cerata was that they were reddish with white tips. The integuments of the cerata were colourless, as could be seen at the tips, where there is no liver; below this colourless tip was a broad band of opaque white, formed by an aggregation of minute dots. The hepatic diverticula were reddish brown.

The foot is expanded anteriorly into a disk, but there are no tentacular angles. The tail does not project beyond the cerata behind. The rhinophores are somewhat longer than the tentacles. In the living animal the cerata show no distinct arrangement in rows; a bare space is visible anteriorly behind the rhinophores; further back the cerata close over and hide the dorsal surface. When stripped off, the cerata are seen to be arranged in ten rows, each containing two to four.

The jaws bear several series of minute denticles. The radula consists of a single series of seventy-six teeth, tapering markedly in breadth. They bear two or three main denticles (Fig. 17.) on each side of the median cusp, and one or two secondary smaller denticles occasionally and irregularly interposed between the main denticles. All the denticles, especially the median cusp, arise unusually far back. $\mathrm{Mr}$. Beaumont states that the penis is armed with a style.

Verril in Proc. U. S. National Mus., iii., 1880, p. 390, observes that Cuthona aurantiaca, A. \& H., is very closely allied to Cratena gymnota (Gould), which has been described by Bergh in Beiträge zur Kenntniss der AEolidiaden, viii., 1885, pp. 33-5. The dentition agrees exactly, but the form and arrangement of the cerata are different, and Bergh found no armature on the penis. It may therefore perhaps be well to keep the forms provisionally distinct.

This form must, I think, be referred to Amphorina, for it has all the main characters of that genus. The cerata are stout (see Alder and Hancock), the penis is armed with a style (according to Beaumont), the radula is tapering, and the denticles on the teeth arise far back. Loman 
in his paper Anteekening over twee voor de nederlandsche Fauna nieuwe Nudibranchiata, published in the Tijdschrift der Nederlandsche Dierkundige Vereeniging, 1893, p. 35, has already called the animal Amphorina aurantiaca.

\author{
AMPHORINA OLIVACEA (A. \& H.). \\ (Alder and Hancock, Mon. Brit. Nud., Fam. 3, pl. 26. \\ Beaumont, l.c., p. 834.)
}

One living specimen was seen at Plymouth in April, 1905, which I should have hesitated to identify with Alder and Hancock's E. olivacea on account of the differences in tint and markings; but Mr. Beaumont considered it referable to this species, and stated that the coloration is very varying. As the other characters of the animal proved to agree with $E$. olivacea, I have no doubt he is correct.

The animal is only $4 \mathrm{~mm}$. long, stoutly built, with a short tail. The body colour is whitish; the tentacle, the rhinophores, and the region behind them are yellowish. There are no red markings, but the cerata and body, especially the head, are sprinkled with conspicuous dots of bright, opaque yellow. The tips of the cerata are whitish and the hepatric diverticula are olive-coloured.

The front of the foot is slightly expanded into round lobes, but there are no tentacular angles. The cerata are rather thick; the branches of the liver within them are of loose and irregular shape. The cerata are set in eight rows, fairly close together, containing three to four each.

The jaws bear a row of minute but distinct blunt denticals. The radula tapers somewhat, but not conspicuously; it consists of a single series of fifty-three teeth, with six denticles on each side of the median cusp (Fig. 18.). This cusp is elevated and rises further back than the others. I found the verge armed with a hooked style (Fig. 19.) as already described by Mr. Beaumont.

I think that this species, like Eolis aurantiaca, A. \& H., must be referred to Amphorina, for it has thick papillæ, a spine on the penis, and a long somewhat tapering radula, in which the teeth have the central cusp rising far back.

\author{
CRATENA AMENA (A. \& H.). \\ (Alder and Hancock, Mon. Brit. Nudib., Fam. 3, pl. 3. \\ Beaumont, l.c., p. 834.)
}

One living specimen, Plymouth, April, 1905. The animal when fully extended is about $75 \mathrm{~mm}$. long. The body is of a not very clear white, with opaque white spots, especially on the head and tail. The angles of the foot are rounded in front. The tentacles and rhinophores are as in 
Alder and Hancock's plate, spotted with white and with a reddishbrown band about a third of the way down. The cerata are spotted with opaque white and brown and have white tips, below which is often, but not always a distinct reddish-brown ring; they are carried as represented by Alder and Hancock, but there are only five or at most six groups, arranged as follows :-

1
4
4
4
4
3

The hepatic diverticula are not nearly as green as represented by Alder and Hancock, but greyish brown with only a faint greenish tinge.

The jaws bear a single row of small but distinct blunt denticles. The radula consists of a single series of seventeen teeth, not tapering conspicuously; there are five denticles on each side of the central cusp, which is not much higher than the rest. Beaumont found the verge to be armed with a colourless spine, but I was unable to discover it.

If Cratena and Amphorina are maintained as separate genera, it is difficult to say to which this species should be referred. Beaumont found that it had a single otolith and a style on the penis, characters which belong to Amphorina; but the cerata are not inflated, the radula is short, and the denticulation of the teeth is not like that found in Amphorina. I therefore describe the animal, though with considerable hesitation, as Cratena amoena.

\section{CALMA, A. \& H.}

Much confusion has arisen about this genus, for later authors have not paid sufficient attention to the statements made about it by Alder and Hancock, and these statements, which are scattered in various parts of the monograph, are not always plain if taken separately, though if taken all together they are clear enough. Alder and Hancock described the type species first in the letterpress to plate 22 (under the name of Eolis glaucoides) as a very curious Eolis which will probably constitute a new generic type, and pointed out the remarkable characters of the "gastro-hepatic vessel" and "the ovary." Their language about the radula in this passage is wanting in precision, but in the letterpress to plate 47 (Tongues of the Eolididae) they say that the tongue is very slender, resembles a continuous band, and can only be seen in profile. The figure clearly represents the tongue as I have found it, a continuous chitinous ribbon in which the teeth are fused 
together and only appear as minute serrulations. On page 21 of the Appendix they create the genus Calma for Eolis glaucoides, but unfortunately mention only the external characters and do not refer to the anatomy.

Hence Trinchese, followed by Bergh (Beit. zur Kennt. der Aiolid., iii., 1876, pp. 643-7, and vii., 1882, pp. 61-4) and Vayssière (Opisth. de Marseille, ii., 1888, 84-8), regarded the genus as akin to Flabellina, and referred to it the Eolis cavolini of Vérany.

Later (Rendiconti Accad. Sci. Fis. Mat. di Napoli, xx. 5, 1881, pp. 121-2, and Mem. Ac. Sci. Istit. di Bologna, S. iv. T. x. pp. 57-61) Trinchese described under the name of Forestia mirabilis a Mediterranean Eolid having all the main characters of Alder and Hancock's Calma glaucoides - the thread-like undivided radula, the broad, simple hepatic system, and the hermaphrodite gland arranged along the two sides of the body. Friele and Hansen had also (Bidrag til Kundskaben om de nordske Nudibranchier, 1875, pp. 78-9) described another species from the Northern Atlantic, calling it merely Eolis albicans, but indicating its affinities to the genus Calma, A. \& H. Bergh, in his System der Nudib. Gasteropoden (p. 1025 and p. 1034) puts Eolis albicans under Forestia, and makes the genus Calma consist of $C$. glaucoides, A. \& H, and C. cavolini (Vérany).

There can, however, be little doubt that the really important characters of Calma are those mentioned above, and that the genus is equivalent to the later (1881) Forestia. It will then contain three species.

(1. C. glaucoides, A. \& H. Atlantic.

12. C. albicans, Friele and Hans. Atlantic.

3. C. mirabilis (Trinchese). Mediterranean.

C. albicans appears closely allied to C. glaucoides. C. mirabilis differs in having a few separate teeth, as well as the continuous chitinous band, and it would seem that the groups of papillæ do not rise from a common stalk.

It seems probable that Calma cavolini does not belong to this genus. It is regarded by Bergh and Vayssière as related to Flabellina, from which it differs in having no perfoliations on the rhinophores. The radula is not like that of Calma glaucoides, but has separate teeth of the usual pattern. There is some doubt whether it is triseriate or uniseriate, the laterals being in any case very small. It would seem that in some points the digestive and reproductive organs resemble those of C.glaucoides, but neither Bergh nor Vayssière suggest that it resembles Forestia mirabilis. They had perhaps not seen Trinchese's paper at the time they wrote. Whatever may be the true affinities of the form, the differences in the buccal parts prevent its being referred to Calma, and I would propose that it should be rebaptized Calmella. 
I do not think that the inflated shape of the cerata and their arrangement on low pedestals are really important characters in Calma, and would define the genus as at present known in the following way.

Animal flattish, cerata arranged in rows and sometimes rising from a pedestal. No cnidocysts. Rhinophores simple. Corners of anterior margin of foot prolonged into tentacular processes. Penis unarmed. Jaws not denticulate. Radula a continuous band not divided into separate teeth and merely bearing serrulations on the upper surface. Digestive system much simpler and less ramified than is usual in the Eolididæ; kidney also simple and not ramified. Hermaphrodite gland symmetrically arranged on the two sides of the body.

Though the anatomy of Calma is characterized by a certain simplicity, this simplicity is no doubt not primitive, but secondarily acquired and connected with the unusual diet of the animal, which feeds on the eggs of fish. The nature of the food no doubt explains the degeneration of the radula and perhaps also the absence of cnidocysts (see Grosvenor, "On the Nematocysts of Eolids," Proc. Roy. Soc., 1903, vol. lxxii. No. 486, p. 469). Several of my specimens seemed to be gorged and distended with gelatinous matter, and probably the creatures' habit of thus stuffing themselves accounts for the breadth and simplicity of the alimentary passages.

\section{CALMA GLAUCOIDES, ALDER \& HANCOCK}

Seven specimens received from the Plymouth Laboratory. Two of them resemble Alder and Hancock's figures more than do the others, which are flatter and have swollen, almost ovate cerata. But no differences of structure were found, and as all the specimens were identified at the Laboratory with $C$. glaucoides, it is probable that they were all alike externally when alive.

The length varies from 10 to 4 and the breadth from 4 to $2 \mathrm{~mm}$. The general colour is whitish or drab, but varies in detail, because the transparent integuments allow the contents both of the body and of the cerata to be seen. The broad digestive tract with its diverticula is generally coloured a pale dull yellow, but contains here and there blackish masses in the cerata as well as in the main alimentary tract. In two specimens these black portions are so large that the general colour appears to be bluish black. At the sides of the body between the cerata the white follicles of the hermaphrodite gland are distinctly visible. The integuments are generally brownish at the sides of the body and at the bases of the cerata.

The margin of the foot is expanded both in front and at the sides, so as to be considerably wider than the head and body; anteriorly the foot is rounded, and is produced on each side into a short tentacular process, 
which is almost invisible in many specimens. The cerata are set in from nine to twelve rows, the most common number being ten. Each row contains two or three cerata, more rarely four. The stalk or common base on which they are set is not at all conspicuous, but when an attempt is made to detach them they come off in twos or threes, and not separately. They are not at all caducous. In most specimens they are oblong-ovate in shape; but in two (as in Alder and Hancock's figures) they are cylindrical. The tentacles and rhinophores are both small, without a trace of perfoliations.

The jaws are thin, smooth, and colourless. The radula consists of a colourless, continuous ribbon, bent into a roughly semicircular shape (Fig. 20.), and bearing 60-100 denticulations like the teeth of a saw, and gradually increasing in size.* No trace of any loose, detached teeth was found. The cesophagus leads into a dilatation (Fig. 21. d.) of moderate size, which may be called the stomach. From it extends a diverticulum on either side which supplies two cerata. Posteriorly the stomach is prolonged into a very wide sacculated gut (Fig. 21. a.), which extends to the extreme end of the body and gives off simple diverticula, each of which supplies a single group of cerata. These diverticula fill the cerata entirely, and no cnidocysts were found. The contents of the digestive tract, including the cerata, resemble hardened jelly, and are probably composed of the eggs of fish, which the animal is said to eat. In this jelly are embedded moderately hard black lumps, detachable from their surroundings and easily friable, which the jelly is not. As mentioned above, in some specimens this black substance forms the major part of the contents of the digestive tract.

The lobes of the hermaphrodite gland are white, and visible through the dorsal integuments. They are composed of small pouches containing ova, scattered rather irregularly round a larger and more elongate pouch containing spermatozoa, and they alternate with the diverticula proceeding from the alimentary canal to the cerata. There is no armature on the penis. The renal organ (Pl. xII., Fig. 22.) consists of a simple sac with a few constrictions. It does not in my specimens extend as far backwards as indicated by Hecht's figures (Contribution à l'étude des Nudibranches, Mem. Soc. Zool. de France, viii. 1895, pl. iv. figs. 47, 48), but terminates soon after the commencement of the posterior third of the body.

\section{JANID压，BERGH.}

This family superficially resembles the true Eolids, but offers several differences of organization. Except in Madrella, the radula is multi-

* Below the row of denticulations (a) there can be seen under a high power three or fuur series of minute pits and projections (b). 
seriate, which would seem to be a more primitive arrangement than the extremely narrow radulæ of the Eolids; but the anal papilla is situated near the end of the back in the median line, which seems to be an instance of secondarily acquired symmetry. The digestive system offers peculiarities of its own; and the cerata, together with the hepatic diverticula, extend in front of the rhinophores along the anterior margin. There is generally a crest between the rhinophores.

Three British genera are known-Antiopella, Janolus, and Proctonotus. The nomenclature of the first genus is confusing. Vérany described it as Janus in 1844, and this name is used by Bergh, Trinchese, and Vayssière on the ground that it has priority over Antiopa, the name used by Alder and Hancock in 1855. But the objection to the name Janus (as pointed out by Alder and Hancock in the text for plate 43) is that it has been in use for a genus of Hymenoptera since 1835. But Mr. Hoyle states (Journal of Conchology, 1902, p. 214) that Antiopa is in its turn invalid for a similar reason, namely, that it was used for a genus of Diptera as early as 1800 . He proposes to call the animal Antiopella, and it would seem that this name must stand, unless some one proves that it also is preoccupied.

Antiopella has perfoliate rhinophores with a crest between them, and jaws with denticulate edges. Only one species is properly authenticated, A. cristata, which is recorded from the Mediterranean and British waters. Janus sanguineus, Angas, is somewhat doubtful. The plate suggests that it may be an unusually red variety of Madrella ferruginosa, which has also the habit mentioned by Angas of discharging a yellow secretion which colours the water round it.

The genus Janolus was created by Bergh for a specimen obtained by the Challenger, and differing from Antiopella in having a very broad margin to the foot and remarkably large undenticulate jaws. Bergh has since shown that Alder and Hancock's Antiopa hyalina belongs to this group. A third species, Janolus coeruleopictus, Eliot, is recorded from California; and a fourth, somewhat doubtful, species is described below.

The genus Proctonotus was created by Alder and Hancock for two specimens found near Dublin, and is also recorded from West Ireland and Arran. The rhinophores are not perfoliate (though they bear wrinkles and tubercles), and there is no crest between them. The radula is broad and the jaws are not denticulate.

\section{ANTIOPELLA CRISTATA (DELLE CHIAJE).}

Four living specimens at Plymouth, April, 1905, the largest $30 \mathrm{~mm}$. long and 8 broad. Alder and Hancock's figure of this species is not very good, and that of Trinchese (Élidida del Porto di Genova, pl. 44) is in 
some respects superior. The general colour is transparent white with a faint yellowish tinge. The rhinophores and the crest between them are very large and distinctly yellowish. On the back and sides of the body and on the tips of the cerata are very vivid metallic spots which appear blue in some lights and pink in others. There is a streak of the same colour on the tail. The hepatic system is of a deep, rich brown, and its ramifications can be seen clearly through the transparent skin.

The cerata are very deciduous, and in these specimens many, or even the majority, are quite small and tubercular. These are evidently new growths replacing lost appendages.

\section{JANOLUS HYALINUS (A. \& H.).}

(Alder and Hancock, Monog. Brit. Nudib., Fam. 3, pl. 44. Bergh, Mal. Untersuch. in Semper's Reisen, vi. 1, p. 8.)

Two preserved specimens from Plymouth, one $8 \mathrm{~mm}$. long, the other only $4.3 \mathrm{~mm}$. They agree as to external characters with Alder and Hancock's description. The colour is yellowish, with traces of lighter and darker mottlings. The cerata are crowded and irregularly set. There are generally four to five in a transverse row. The innermost are the largest and about $5 \mathrm{~mm}$. high; they decrease in size outwards, and the outermost are mere tubercles. They bear knobs, as described by Alder and Hancock. The anterior margin of the foot is somewhat undulated, with a bend inwards in the middle. It is not grooved in the ordinary way, but the sides of the head are developed into lappets which extend downwards towards the sides of the foot and form a ridge parallel to them. There is a small fold round the head bearing two distinct tentacles. The rhinophores bear irregular perfoliations which do not go all round the club. The interrhinophorial crest is elongate.

The jaws are large and smooth, with no denticles. The radula consists of fifteen rows varying from 11.1.11 to 13.1.13. The teeth are hamate and increase in size from the rhachis outwards, the last but one being the largest, and the outermost of all smaller (Fig. 23.). They bear three to five (rarely seven) long ridge-like denticles, which are not very small, but difficult to see on account of the extreme transparency of the teeth. These denticles seem to have escaped the notice of both Alder and Hancock (Tongues of the Eolididce) and Bergh, who describe the teeth as smooth. The denticulation is probably variable.

Alder and Hancock's figures of this species (Monograph, pl. 44, figs. 8 to 12) are not good, but much better unpublished drawings by Hancock are preserved in the Newcastle Museum.

JANOLUS FLAGELLATUS, $s p$. nov.

One specimen from Plymouth labelled "Antiopa hyalina $n r$. Eddystone 
25. vi. 97." As preserved, it is of a uniform dull-white colour, slightly transparent on the back, but elsewhere opaque. The length is $15.5 \mathrm{~mm}$.; the breadth 8 ; the height to the top of the pericardium $7 \cdot 5$, but the end of the body has burst open, and the hermaphrodite gland is protruding. The foot is broad (as much as $9.5 \mathrm{~mm}$. in one place), with ample and undulated mantle margins. It is notched in front, and connected with the head by two very distinct intermediate fleshy plates. Above them are two small but distinct tentacles, forming the extremities of a narrow oral veil. The rhinophores are straight, cylindrical, moderately stout, and bear irregular but distinctly vertical perfoliations, which often join one another or end abruptly before they reach the summit. Between them is a very distinct crest, consisting of about ten transverse perfoliations, which are themselves crinkled and again perfoliate.

The only cerata preserved are minute, not more than $1 \mathrm{~mm}$. high, more numerous on the right than on the left, and set in one to two rows. There are also several small cerata in front of the rhinophores. There is no trace of larger cerata, but they have probably been lost and replaced by young ones in the first stages of growth. The anus is medio-dorsal, set very far back, and cup-like. There appear to be a few tubercles on the broad tail.

The genital orifices are about $5 \mathrm{~mm}$. from the head and surrounded by strong folds. The verge is exserted and extremely long. It consists of a straight cylindrical column, not tapering, $4 \mathrm{~mm}$. long, and bearing at the end a flagelliform appendage $5 \mathrm{~mm}$. long, so that the whole organ measures $9 \mathrm{~mm}$.

The digestive organs are much compressed by the greatly developed reproductive glands and are not very well preserved, but appear to agree with Alder and Hancock's account of Antiopa cristata. The œsophagus is short and opens into a large laminated stomach, from which the intestine runs backwards and which receives the two principal hepatic trunks. Owing to the cerata being minute and rudimentary the course of the hepatic diverticula in them cannot be traced; but beneath the dorsal skin, and especially at the sides, there is a thick network of tubes out of which the hepatic trunks seem to arise.

The central nervous system is like that described by Bergh for Janolus australis, and the eyes have long connectives.

The buccal mass is large $(5 \mathrm{~mm} . \times 4 \mathrm{~mm}$.) and yellowish white. The jaws bright, deep orange, very thick and strong, as in Janolus hyalinus. The radula consists of fifteen rows, with a maximum formula of 20.1.20. The lateral teeth (Fig. 24. b.) are yellow, hamate, low, with a large, broad base. The median teeth (Fig. 24. a.) are small, with a low inconspicuous hook. No denticulations could be seen. 
The hermaphrodite gland is very large, and fills the whole posterior part of the body with numerous packets of yellowish-white follicles. The anterior genital mass is enormous $(10 \mathrm{~mm} . \times 7 \mathrm{~mm}$.) for the size of the animal, and both the mucous and albumen glands are greatly swollen. The spermatotheca is elliptical. The verge is as described above; the canal follows the whole length of the flagellum to the very end.

It would seem that the flagelliform character of the verge distinguishes this species from J.hyalinus. No such formation is indicated in Bergh's description of $J$.hyalinus, nor have I found it myself in that animal. Also there seem to be some differences in the radula; and though the shape of the cerata is: unfortunately unknown, the general appearance and dead-white colouring do not resemble $J$. hyalinus. But the species is open to doubt unless confirmed by other specimens.

\section{ALDERIA, ALLMAN.}

Three species of this genus have been described.

1. A. modesta (Lovén).

2. A. comosa, A. Da Costa. Naples (Ann. del Museo Zoologico, Napoli, anno iv. 1864 , p. 32 , and pl. ii. 3 ).

3. A. harvardiensis (Agassiz). East coast of North America (see Gould, Invertebrata of Massachusetts, 1870, pp. 254-5, pl. xvi. 226-8).

Alder and Hancock published some account of the anatomy of A. modesta in their monograph, but only the external features of the other two species are known. A. comosa is green, with numerous long cerata, and the anal papilla lies behind the pericardium. It must be regarded as very doubtful if $A$. harvardiensis is really distinct from A. modesta, which differs in being darker, in having fewer and smaller cerata, and, if Gould's figure may be trusted, in the more angular shape of the head. But the description and the figure do not quite agree as to the disposition of the cerata, and the colour of $A$. modesta is very variable.

Alderia seems allied to Limapontia, from which it differs chiefly in having cerata and a much greater ramification of the hepatic system. The lateral expansions of the foot remind one of the wings of Elysia.

ALDERIA MODESTA, LOVEN.

(Alder and Hancock, Monog., Genus 17, Fam. 3, pl. 41.)

I am indebted to Mr. W. I. Beaumont for several specimens of this interesting form, labelled "Ardfry, County Galway, May 1904." In some unpublished MSS. of Albany Hancock preserved in the Hancock 
Museum at Newcastle-on-Tyne I have found the following notes on the living animal :-

"The foot exhibited beautiful dendritic markings. ${ }^{*}$ The glands in the papillæ are considerably branched. The animal yields a quantity of mucus, has a strong sugar smell, and is sluggish in its motions. The papillæ are remarkable for their rhythmical pulsations. They dilate and contract simultaneously between thirty and sixty times a minute. The contraction is very forcible, the posterior surface of the papillæ being most contracted. This pulsation has all the appearance of being connected with the circulation. The papillæ are much depressed when in a state of contraction."

The colour of the preserved specimens varies from white to yellow, with darker mottlings on the back and upper side of the cerata. The variations in shade are considerable. Sometimes the ground colour is yellowish and the mottlings light, leaving a general impression of yellowish brown. Sometimes the mottlings are thick and dark and the ground colour opaque white. The upper surface then appears to be purplish black, with a few white markings.

The animals are stoutly built, the largest specimens measuring $5.5 \mathrm{~mm}$. by about 3.5 . In front the dorsal surface is bare, the cerata being set only at the sides, but behind they close over the body. The foot is white, broader than the body, with an expanded margin, but rather straight in front. No anterior groove is visible.

At the sides there is a groove between the body and this margin, so that the body, though narrower than the foot, partly overhangs it. On this lateral projection of the body are set the cerata in three not very regular longitudinal rows. As a rule only two rows are fully developed, and the third, which consists of smaller cerata, has the appearance of being crowded in. The total number of cerata on either side does not appear to exceed fifteen, which is less than the number shown in Alder and Hancock's plates. The cerata are somewhat ovate in shape. Those behind are larger and more inflated than those in front. They contain ramified hepatic diverticula which bear primary and sometimes short secondary branches.

The head bears on each side a rounded prominence, but there are neither rhinophores nor tentacles in the ordinary sense. The anus is on a prominent papilla in the medio-dorsal line and nearly terminal.

There is no trace of jaws. The radula is ascoglossan and short, containing five or six teeth in the ascending, and about as many in the descending portion. In an irregular heap lie about seven teeth of varying size, and with them a mass of minute spines, apparently repre-

\footnotetext{
* Due apparently to the ramified diverticula of the alimentary canal being seen through the semi-transparent sole.
} 
senting the first teeth. The mature teeth (Pl. XI., Fig. 25.) are large and spoon-shaped. The outline is rather irregular, and there are generally two more or less distinct projections on the back.

There is no crop attached to the buccal mass, but from it issues a thin tube (Fig. 26. a.) which must apparently be regarded as equivalent to a stomach as well as to an osophagus, at least in its posterior part, for from it arises the intestine (Pl. XII., Fig. 26. b.). This is a larger tube which bends slightly to the right and then runs directly backwards at first on the right under the side of the pericardium and finally above the renal organ to the anal papilla (Fig. 26. c.). The thin tube issuing from the buccal mass bears two folds inside. At its posterior extremity these folds become more numerous, and the tube bends downwards and dilates into a large stomach-like pouch (Fig. 26. e.). It is clear, however, that the intestine does not issue from this pouch, but from the narrower tube. It is probable that the animal lives on vegetable juices, and that the two folds in the tube act as strainers and valves, establishing communication alternately between the mouth and the pouch and between the pouch and the intestine, only one line of communication being open at a time. The pouch is prolonged anteriorly under the oesophagus and divides into two diverticula (Fig. 26. d.) which enter the anterior lobes of the foot. Posteriorly it extends almost to the end of the body and gives off two sets of ramifying diverticula (Fig. 26. f.). The upper diverticula (about four in number) enter the cerata and are also ramified in the body. The lower diverticula (also about four) extend downwards through the hermaphrodite gland and do not enter the cerata, but their ramifications within the body create the peculiar dendritic markings (Fig. 28. i.) visible through the sole of the foot.

The central nervous system (Pl. XI., Fig. 30.) forms a collar round the œsophagus consisting of seven principal ganglia close to one another and connected by very short commissures, the longest being that connecting the cerebral ganglia. They should probably be regarded as two cerebral, two pedal, and three visceral ganglia. Connected with the cerebral ganglia are two smaller ganglia, probably rhinophorial in function and innervating the most sensitive part of the head, although no external rhinophores are developed.

The hermaphrodite gland is large and ramified throughout the whole lower part of the body, filling up the interstices between the other organs. The ampulla and duct of the gland are short. After the bifurcation of the male and female branches (Pl, XII., Fig. 27. b.) the former runs to an orifice at the right anterior corner of the head. The vas deferens (Fig. 27. d.) is not very long or much convoluted. A rather large prostate (Fig. 27. c.) opens into it by several ducts. The penis is armed with a rather long curved spine which in some specimens at any rate 
points inwards when the organ is retracted. Shortly after the bifurcation the female branch receives a long duct (Fig. 27, g.) into which open the follicles of the albumen gland (Fig. 27. h.). This gland, like the hermaphrodite gland, is extensively ramified, especially in the last fourth of the body. Close to the entry of this duct and lying anteriorly is a pouchlike diverticulum (Fig. 27. f.) which is probably a spermatotheca. No second spermatotheca was found. The female branch here makes a sharp turn and runs backwards nearly to the end of the body; it then doubles on itself and runs forwards, opening anteriorly close to the male orifice. All this section (Fig. 27.i.) of the female branch after the spermatotheca is very much larger than the other parts and provided with remarkably thick glandular walls. It should probably be regarded as the uterus passing through the mucus gland. It is one of the largest and most conspicuous organs in the animal, and when sections are cut it generally expands and overlaps the heart and kidney.* This, however, appears to be the result of the disturbance caused by the cut, and not a natural arrangement. It is noticable that near the bifurcation of the male and female branches there arises a cœcum which extends anteriorly and reaches the integument, but without forming any orifice. Pelseneer states (Recherches sur divers Opisthobranches, p. 62) that in Elysia the second female orifice is developed later than the others and is not found in young individuals. It is conceivable that this cœeum in Alderia may ultimately open externally.

The pericardium appears to be as usual and is medio-dorsal. The renal organ (Fig. 28. k.) lies below it and is entire in the front, but the posterior portion gives off ramifying tubes, some of which extend into the cerata.

Blood lacunæ are distributed throughout the body, including the foot. The largest lie one on either side of the renal organ below the cerata, into which they send up long diverticula; the main portion of these diverticula lies on the posterior side of the cerata, which no doubt accounts for the peculiar pulsation and contraction noticed by Alder and Hancock in this part.

\section{STILIGER BELLULUS (D'ORBIGNY).}

)=Calliopcea bellula, D'Orвigny. Mag. de Zool., 1837, pp. 12 to 14 . Stiliger maria, Berge. Mal. Unt. in Semper's Reisen, Heft iii, 1872, pp. 137, 144 ; Id. Beit. zur Kennt. der Eolid., v. pp. 12 to 17.)

Bergh has published two detailed description of this species, which I notice here merely to mention that it apparently ought to be called St. bellulus and not St. marice.

* This dislocation seems due to the elasticity and expansive power of the tissues which form the walls of the uterus.

NEW SERIES, - VOL. VII. NO, 2 
The genus was created by Ehrenberg (1831) for an animal found in the Red Sea and having the same external characters as this species, though the radula is unknown. Until the original Stiliger ornatus (not modestus, as it is sometimes quoted) is re-examined, some doubt must exist as to the identity of Calliopoea and Stiliger, though that identity is highly probable.

In 1837 d'Orbigny gave the name of Calliopcea bellula to a molluse whose external characters are quite recognizable from his description. In 1865 Meyer and Möbius (Fauna der Kieler Bucht) described an apparently identical animal as Embletonia marice, wrongly regarding it as an Æolid. Bergh refers both forms to Stiliger and brackets them together, but gives the preference to Meyer and Möbius's name, although d'Orbigny's name has undoubted priority if his species is admitted to be a Stiliger.

Through the kindness of Mr. Farran I have received three specimens from Ballynakil, Co. Galway. They are indifferently preserved, and have lost some or all of the cerata. The best specimen is $7 \mathrm{~mm}$. long and has thirteen cerata remaining. They were apparently set in two rows, and are of an ovoid shape. The posterior cerata of the inner row are relatively very large $(2 \mathrm{~mm}$. high). The rhinophores are distinct and white.

The ground colour is greyish white, with brownish or olive markings on the cerata and body. The foot is greyish white without markings. The opaque white internal organs, especially the hermaphrodite gland, can be seen through the integuments.

The radula contains five teeth in the ascending and twelve in the descending slightly spiral portion. They are as represented by Bergh, but so transparent that they are seen only with difficulty.

The species is recorded from Kiel, West Ireland, the Atlantic coast of France, and Trieste.

\section{LIST OF FIGURES.}

(Plates XI. and XII.)

1. Tritonia alba. a. rhachidian tooth; $b$. first lateral; $c$. second lateral ; d. e. f. laterals from middle of half-row ; $g$. outermost tooth.

2. Archidoris testudinaria. a. b. c. teeth from the inner part of the half-row ; $d$. tooth with an abnormal projection; e.f. teeth from the outer part of the row.

3. Lamellidoris oblonga. a. inner tooth; $b$. outer ditto.

4. Lamellidoris depressa. $a$, inner tooth; $b$. outer ditto. 
5. Lamellidoris pusilla. Inner tooth.

6. Lomanotus genei. A marginal papilla.

7. Lomanotus genei. Teeth. a. $a$. $a$. from the middle of the radula; $b . b$. further from the middle; $c$. still further from the middle.

8. Lomanotus genei. Edge of jaw with denticulate scales.

9. Lomanotus marmoratus. a. b. teeth; $c$. a large papilla.

10. Hancockia dactylota. A row from the radula. $a$. median tooth; $b . b$. laterals.

11. (Plate xII.) Hancockia dactylota. Diagram of the digestive system. The intestine and upper part of the stomach are drawn in yellow, the rest of the digestive system in black. $a$. œsophagus; $b . b$. diverticulum on œsophagus ; $c$. stomach ; $d$. intestine ; e. anus ; $f$. $f$. anterior diverticula ; $g .^{1}-g{ }^{4}$ branches supplying the cerata; $h$. secondary ramifications in the cerata existing on all the main branches, but only drawn here; $i$. posterior prolongation of the stomach.

12. (Plate xII.) Hancockia dactylota. Transverse section through the anal papilla and renal opening. $a$. intestine ; $b$. stomach; $c$. $d$. anterior diverticula ; $e$ anal papilla; $f$. kidney; $g$. renal orifice; $h$. heart; $i$. blood lacunæ; k. pericardium; $l$. hermaphrodite gland; $m$. duct of albumen gland; $n$. two lobes of hermaphrodite gland.

13. (Plate XIr.) Hancockia dactylota. A longitudinal section through one of the cerata. $a$. the intestine running forward; $b$. œsophagus; $c$. anterior hepatic diverticulum ; $d . d$. branches of ditto within the cerata ; $e$. external orifice of one of these branches and cnidopore (?) ; $f$. blood lacunæ ; $g$. kidney.

14. Doto pinnatifida, var. papillifera. A rhinophore sheath with papillæ.

15. Coryphella beaumonti. $a$. central tooth; $b$. lateral tooth.

16. Coryphella beaumonti. Cones from the penis.

17. Amphorina aurantiaca. Teeth.

18. Amphorina olivacea. a. a tooth.

19. Amphorina olivacea. End of penis with stylet.

20. Calma glaucoides. Radula. From a microphotograph.

21. Calma glaucoides. Diagram of digestive system. a. a. a. the gut and its prolongations into the cerata ; $b$. integuments of body and cerata ; $c$. buccal mass, $\varnothing$ hermaphrodite gland; $d$. stomachic dilatation.

22 Calma glaucoides. Renal organ (shown in black) with the heart and pericardium (shown in red). $r$. o. renal orifice; vent. ventricle; aur. auricle; pc. pericardium; $r . p$. o. reno-pericardial orifice.

23. Janolus hyalinus. A tooth.

24. Janolus flagellatus, $a$, median tooth seen from side; $b$. a lateral tooth.

25. Alderia modesta. A tooth.

26. Alderia modesta. Diagram of digestive system. $a$. œesophagus; $b$. intestine ; $c$. anal papilla ; $d$. $d$. anterior diverticula ; e. stomachic pouch ; f. f. posterior diverticula.

27. Alderia modesta. Diagram of reproductive system. a. ducts of hermaphrodite gland; $b$. bifurcation of the male and female branches; $c$. prostate; $d$. vas deferens; $e$. penis ; $f$. a pouch which is probably the spermatotheca ; $g$. the duct of the albumen gland; $h$. the albumen gland; $i$. main channel of the female organs, which should probably be regarded as the uterus passing through a mucus gland. The hermaphrodite portion of the organs is coloured orange, the male portion black, and the female red. The arrow indicates the point at which the section represented in Fig. 29 is cut, 
28. Alderia modesta. A longitudinal section cut slightly to the left of the median line and not quite sagittal. It does not show the mouth and buccal mass very distinctly, but gives a better view of the rest of the digestive tract than is obtained by a median section. $a$. left side of mouth; $b$. left side of buccal mass; $c$. left side of central nervous system; $d$. œsophagus; $e$. tube with laminated walls running into the stomachic pouch; $f$. point where the intestine commences, the intestine runs somewhat to the right but reappears for a moment at $f^{1} ; g$. stomachic pouch ; $h$. anterior diverticulum of the pouch; i. $i$. $i$. lateral diverticula in the foot and cerata $; j$. albumen gland; $k$. renal organ ; $l$. uterus (the organ marked $i$. in Fig. 27), which on being cut has expanded and spread dorsally at the expense of the renal organ and pericardium ; $m$. portions of the hermaphrodite duct containing masses of spermatozoa; $n$. prostate. The remaining parts of the drawing are mostly lobes of the hermaphrodite gland.

29. Alderia modesta. Transverse section cut at the point marked by an arrow in Fig. 27. e. h. l. n. as in the longitudinal section (Fig. 28); f. the intestine passing over to the right side; $i$. $i$. latero-dorsal diverticula of $h$.; m. a prolongation of the hermaphrodite duct; $o$. the female branch running forward into a pouch (? spermatotheca); $p$. ditto running backwards from the pouch ; $v$. vas deferens ; $s$. one of the prostatic tubules entering into the vas deferens.

30. Alderia modesta. Central nervous system. a. right cerebro-pleural ganglion; $b$. right pedal ganglion; $c$. right visceral ganglion; $d$. median visceral ganglion ; $e$. left pedal ganglion ; $f$. left visceral ganglion; $g$. left cerebropleural ganglion. 
Journ. Mar. Biol. Assoc. Vol.VII.

Plate XI.

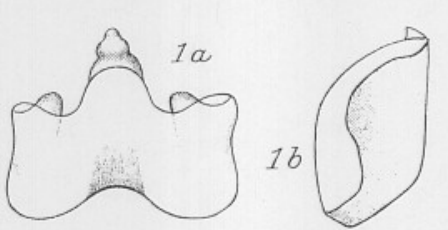

$2 a)(2 b)$

$3 a \overbrace{2}^{3 a}$

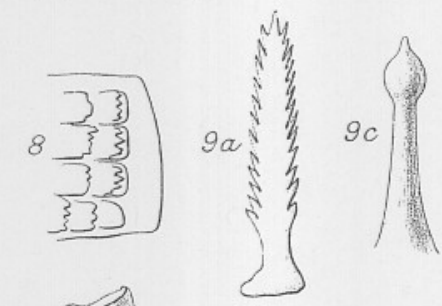

$14 \int_{2}^{2}+24 a=3$

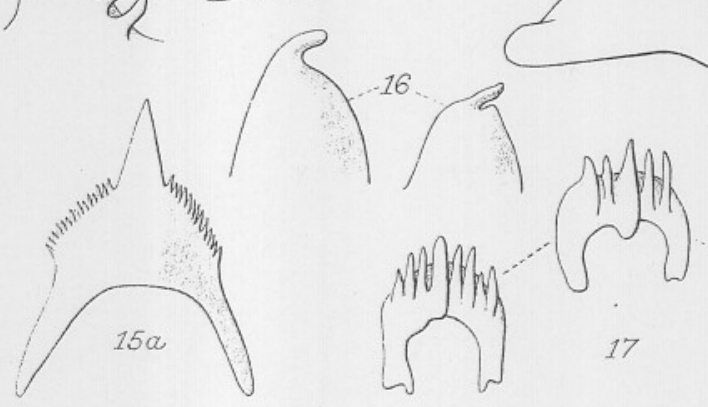

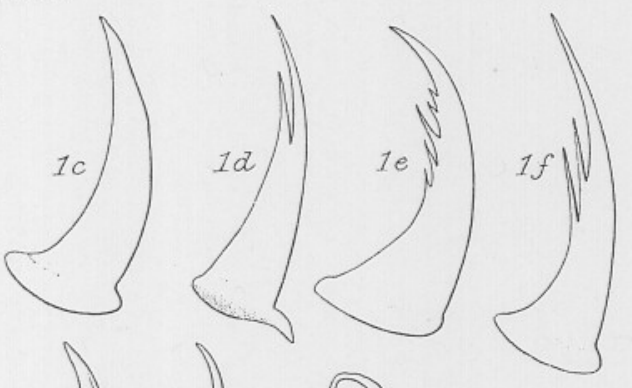

2.) 28 ?
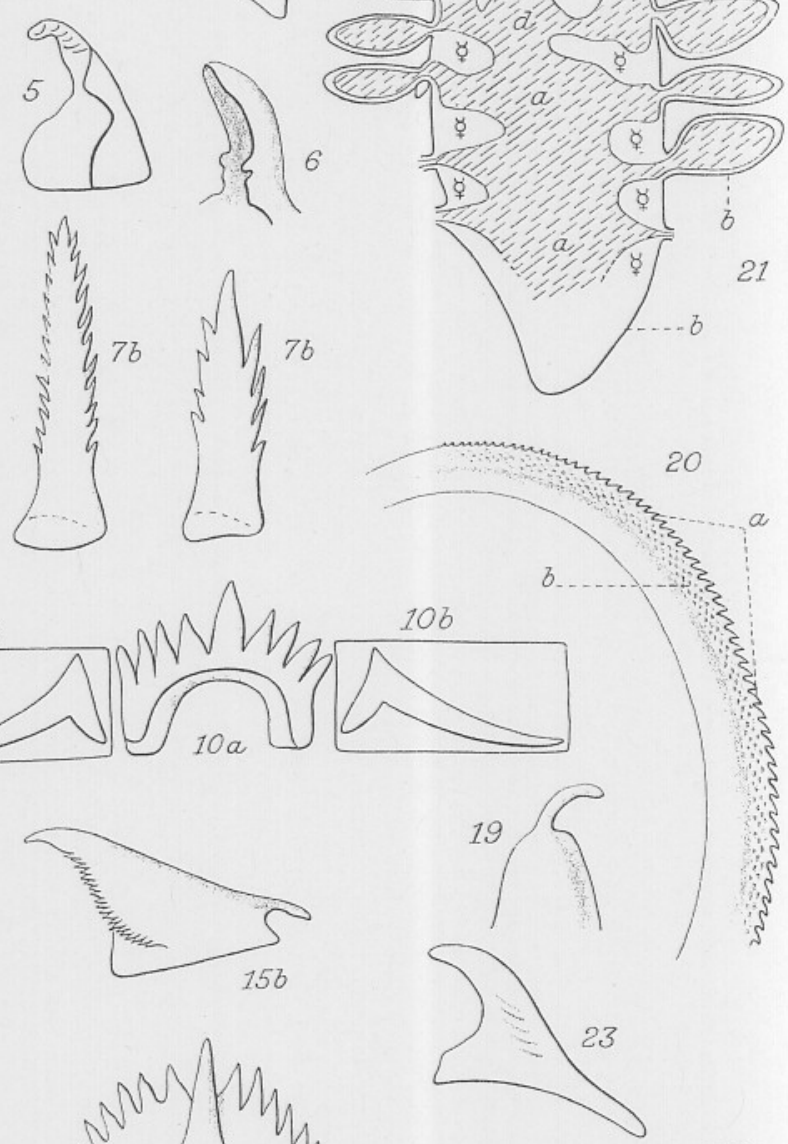

20

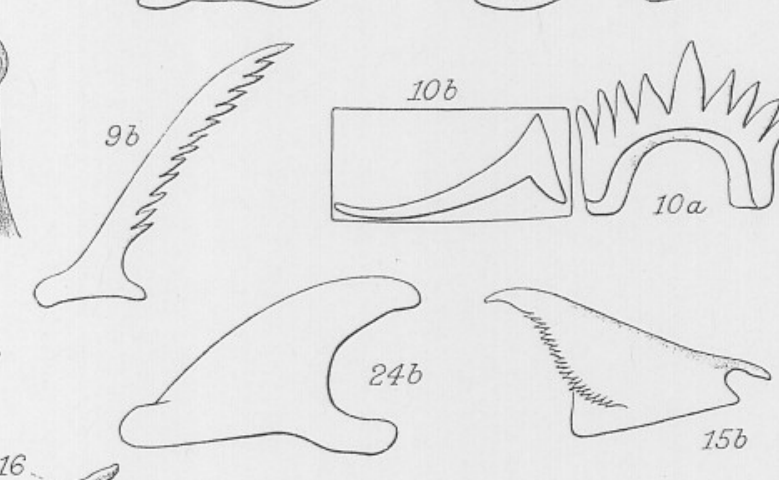


Journ. Mar:Biol. Assoc. Vol.VII.

Plate XII.
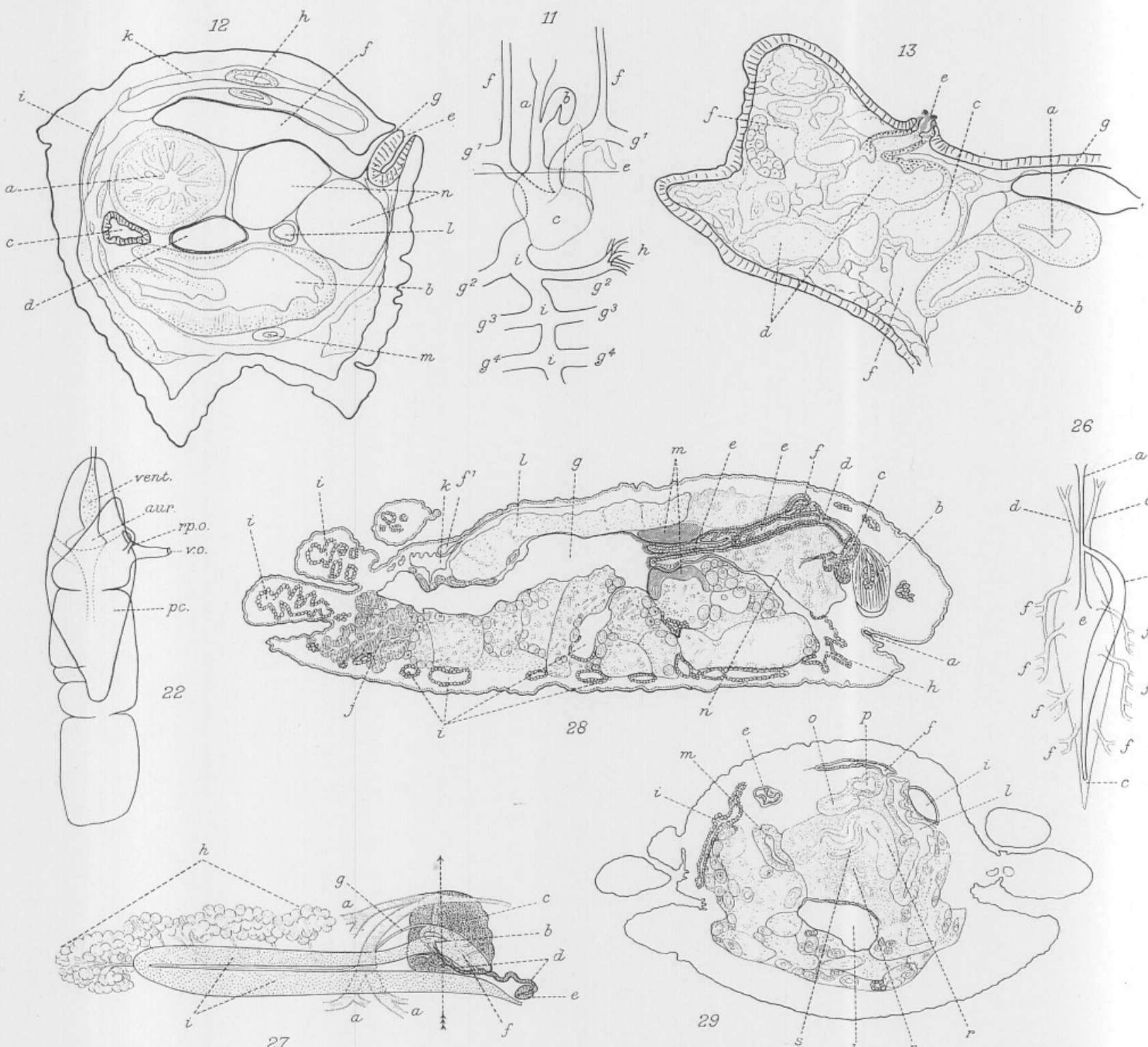

27

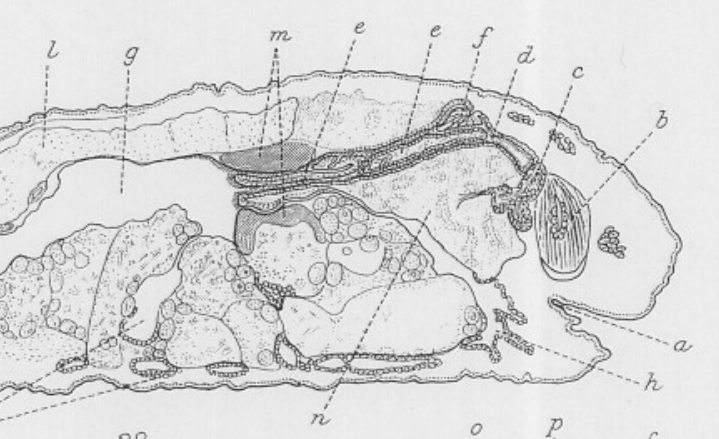

28

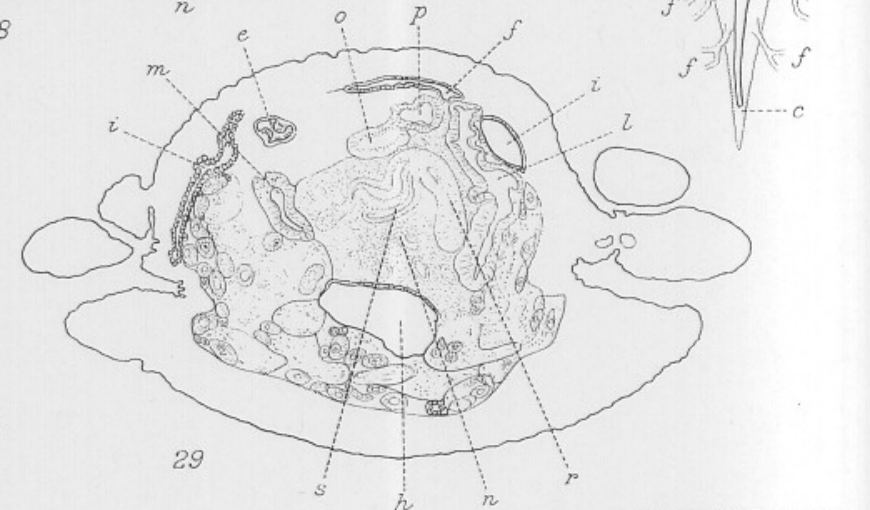

Figs 11-13, 22, 26-29. 